This is a Preprint and has been peer reviewed and accepted in the Bulletin of the Geological Society of Malaysia.

Cite it as:

Shah A.A., Syaakiirroh Sahari, Navakanesh B., Nurhafizah A.M., Fu Fui, AshwiniandTalha Q.Title 2022. Tectonic geomorphology of the Jhelum fault zone and its contiguous regions in western Himalaya. Bulletin of the Geological Society of Malaysia, Vol. 73 May 2022. 


\title{
Tectonic geomorphology of the Jhelum fault zone \& its contiguous regions in western Himalaya
}

\author{
Shah A. A. ${ }^{1}$, Syaakiirroh Sahari ${ }^{1}$, Navakanesh B ${ }^{2}$, Nurhafizah A.M. ${ }^{1}$, Fu Fui ${ }^{1}$, Ashwini ${ }^{1}$, Talha Q. ${ }^{1,3}$ \\ Department of Physical and Geological Sciences, Universiti Brunei Darussalam, Brunei Darussalam ${ }^{1}$ \\ Southeast Asia Disaster Prevention Research Initiative, Universiti Kebangsaan Malaysia² \\ Department of Earth Sciences, University of Toronto, Toronto, Canada ${ }^{3}$ \\ Corresponding author email: $\underline{\text { afroz.shah @ ubd.edu.bn }}{ }^{1}$
}

\begin{abstract}
The western Himalayan syntaxis represents the region where the major Himalayan structures abruptly curve and the cause of the curvature and the tectonic geomorphology of the region has not been fully explored. The lack of detailed structural maps with extensive field-based data is missing, which is mainly because of the political problems related to border sharing between Pakistan, India, and Afghanistan. However, and fortunately, the usage of satellite-derived images has overcome such constraints by providing a robust platform to remotely map such regions. Therefore, the present study was aimed to supplement our previous works in the region by exploring the western portions of the Hazara-Kashmir-Syntaxis. We have used Google Terrain imagery to map the evidence for active faulting that involves mapping of triangular facets, displaced and/or faulted topographic ridges, river terraces, alluvial fans and so on. The cross-cutting relationships are used to date the faulting events where absolute dates are not available. Our results show that active tectonic deformation is not just limited to the previously mapped structures (e.g. the Kalabagh Fault, the Salt Range Thrust, the Mahesian Anticline, and the Jhelum Fault) but occurs on a broader deformation zone that is delimited by the Chaman fault system in the west, and the Jhelum fault in the east. The deformation zone in 3D resembles a tectonically formed diamond-shaped box that has the Salt-Range thrust in front and the Main boundary thrust fault at the back with sides delimited by the Chaman and the Jhelum fault systems. The earthquake centroid moment tensor data complements our geomorphological work and establishes that transpression is a dominant tectonic process that governs the western regions, which is in comparison to the east where transtension is the norm in the interior Himalayan with reverse and thrust faulting dominant in the frontal regions.
\end{abstract}

Keywords: Jhelum, Himalaya, Strike-slip fault, Thrust fault 


\section{Introduction}

The Himalaya orogenic system is a textbook example of the continent-continent collision that involves lithospheric plates of India and Eurasia since Eocene (Ni \& Barazangi, 1984; Avouac, 2007; Shah et al., 2020; Ghani et al., 2020). The geomorphic and topographic expression of the collision is usually represented by a variety of tectonic and geomorphic features that include the development of fold and thrust belts, intermontane basins (e.g. Peshawar and Kashmir; Fig. 1A) etc. The structural geology of a typical collisional mountain belt is generally preserved through the formation and development of major structural fabric at micro and macro scales, which to a large extent are systematically oriented and represent the kinematics associated with the history of plate convergence. For example, the formation of major fold-\&-thrust belts during the lithospheric plate convergence is usually expressed by a stack of structures in the Himalayas (Fig. 1a), and chronologically it includes the Main Mantle Thrust (MMT), the Main Central thrust (MCT), the Main boundary thrust (MBT), and the Main Himalayan/frontal thrust (MHT/MFT) fault systems. These faults have juxtaposed different lithological units against each other (e.g. Yin \& Harrison, 2000) and such abrupt stratigraphic changes are usually coincident with the faults (Fig. 1). The Jhelum fault (JF) is one of the active fault systems in NW Himalaya (Shah et al., 2020) and it marks the eastern boundary of the Potwar Plateau where active deformation is mainly accommodated on the reverse and frontal fold and thrust belt (Fig. 1). The physical location of the Jhelum fault marks a sharp transition (Fig. 1) where the major Himalayan structures abruptly turn (Bossart et al., 1988; Shah et al., 2020) and delineate the position of the Hazara-Kashmir Syntaxis (HKS). Although the trace of the JF has been inferred on the basis of seismicity, and geomorphic features (Baig \& Lawrence, 1987) but the details were largely missing, which include the mapping of the actual trace of the fault, geomorphic features related to active faulting, a detailed examination of the earthquake moment tensor data and its relation with the active faults etc. These details are recently covered in Shah et al. (2020), and here we extend our previous work to cover the additional areas in the eastern portion of the JF system to map and understand the cause and formation of active geomorphic features in the region. The motivation is to understand how active deformation in the eastern portions of the HKS differs from what is actively happing in its west. We are also trying to explore and answer the fundamental question about the cause of out-of-sequence thrusts (OOST) in the region. These faults could pose serious seismic hazards (Shah et al., 2020) because the faults do not conform to the general rule of foreland propagating or in-sequence deformation pattern (Morley, 1988), and therefore, poses questions about the activation of such faults in the future. 
We have deliberately used the Google terrain satellite images to map the tectonic geomorphology of the region (Fig.1 A) to demonstrate the robustness and usability of these easily available satellite images. The images are easy to process unlike the shutter radar topography and other similar datasets, which routinely require either a competent software application (e.g. ArcGIS etc.) to retrieve and process the data or continuous internet access. Therefore, it usually causes hindrance to many young researchers who have no access to such expensive tools because of funding constraints, and lack of resources to use persistent and high-speed internet further restricts their research ambitions (Qadri \& Shah, 2020).

\section{Geological, Political and Tectonic setting}

The tectonic convergence between the lithospheric plates of India and Asia resulted in the formation of a broad collision zone between the plates, and it has also created one of the most pectoral landscapes of the world, the Himalayas, that have attracted explorers and visitors throughout the world (Aug, 1907; Swan, 1961; Le Fort, 1975; Powell \& Conaghan, 1973; Yin, 2006; Shah, 2015; An et al., 2021). However, the political landscape of the region has been complicated, which has equally created a political collision zone that involves Pakistan, India, China and Afghanistan, and it has largely hampered the geological work (Shah et al., 2018), and in particular the international collaborations on the geological and tectonics aspects of the region. Therefore, the available geological and tectonic information about the region is not complete, and we have only selected and used reliable sources (references herein) to reproduce the geological and tectonic map of the region (Fig.1B).

The exact timing of the start of the collisional tectonics between India and Asia is controversial with some arguing the continental suturing at 34Ma (Aitchison et al.,2007), and some at $61 \mathrm{Ma}$ (An et al., 2021). The onset of the tectonic collision resulted in the nucleation of a broad zone of thrust and fold belt, which is rooted on a series of thrust faults that are progressively younger towards the south of the suture zone (Yin, 2006; Yin \& Harrison, 2000). The active strike-slip and normal faults are mostly limited towards the north (Shah et al., 2020) while as the thrust and reverse faults are dominantly active in the south. The geological map shows the study area is dominated by the Subhimalaya rocks, which quite think on the map view as compared to what is observed in the eastern portion of the NW Himalayas (Fig. 1). The frontal portions are demarcated by the Salt Range thrust that has exposed and juxtaposed the slices of the Lesser and Tethys Himalayan rock sequences with the Sub-Himalayas (Fig. 1). The northern portion of the study area is limited by the Main Boundary Thrust (MBT) fault and north of it the Lower Proterozoic Metamorphic rocks are exposed, which is unique to this part of the Himalayas as similar rocks are not exposed anywhere else (Fig. 1B). 
The Indus-Tsangpo Sutute Zone and associated rocks form the eastern limit of the study area and such rocks only outcrop in the Ladakh regions in the east. The regions between Ladakh and Peshawar are largely devoid of such rocks, which is where the deep-rooted rocks are exposed and indicate faulting and exhumation that is not observable anywhere else in the Himalayas (Fig. 1B).

The geological and tectonic maps (Fig. 1B) shows a major bending of lithological and structural trends, which coincides with the emergence of the sinistral strike-slip fault, the Jhelum fault system (Shah et al., 2020). The lithological map shows a clear sinistral offset along the trace of the Jhelum fault, which delimits the Potwar fold and thrust belt from the western regions (Fig. 1B). The Salt Range thrust system bounds the northern limit of the Potwar region, which has been displaced by the dextral strike-slip fault, the Kalabagh fault system (Butler et al., 1987; McDougall \& Hussain, 1991; Chen \& Khan, 2010; Ghani et al., 2018). The Hazara-Kashmir-Syntaxis is a complex stack of overlapping thrusts with Precambrian, Palaeozoic, and Mesozoic formations on top of the Tertiary Murree Formation (Bossart et al., 1988; 1990; Shah et al., 2020). The three major Himalayan faults are observed to rotate at the emergence of the HKS (Bossart et al., 1988; 1990; Butler, 2019), and these are the Main Central Thrust (MCT), Main Boundary Thrust (MBT) and to a lesser extent the Main Frontal Thrust (MFT). These major fault systems have developed over the geological past and preserve evidence of the plate convergence between India and Asia (Yin \& Harrison, 2000; Yin, 2006). The Main Central Thrust (MCT) fault system is a north dipping form zone with a thick zone of deformed rocks that are usually characterized by different degree of shearing and imbrication (Catlos et al., 2001). It is the older fault zone in the series of faults that show younging towards the south, which indicates the insequence style of thrusting (Morley, 1988). The thickness of this shear zone is estimated to be a few kilometres up to $>10 \mathrm{~km}$ thick (Yin \& Harrison, 2000). Moreover, Yin (2006) also mentions that this fault is broadly folded and juxtaposes high-grade gneisses and schist over either steely dipping limestone or subhorizontal quartzite. The Main Boundary Thrust (MBT) is a reverse fault that dips steeply towards the north (Meigs et al., 1995). It demarcates the pre-dominantly lesser Himalayan sediments against the Siwalik Formations. Burbank et al. (1996) argue that the fault is about $11 \mathrm{Ma}$, which was followed by the formation of the Main Himalayan/Frontal thrust fault that separates the Siwalik Group strata from the Indo-Gangetic plains (Yin, 2006), and represents the present-day megathrust fault between the two lithospheric plates in the collision (Fig. 1B).

The Jhelum fault is a major $\sim \mathrm{N}-\mathrm{S}$ trending active sinistral strike-slip fault that truncates the $\sim \mathrm{NW}$-SE structural fabric of the NW Himalayas, and its location coincides with the abrupt turning of the major structures (Fig. 1B) and has 
therefore played a major role in the formation and rotations of structures and basins in the region (Shah et al., 2020). The other active faults are the Kalabagh Fault, the Salt Range Thrust, the Mahesian Anticline, and the Chaman fault (Cortés-Aranda et al., 2017; Ghani et al., 2020). The pattern of Holocene faulting has been related to in-sequence deformation, which is in contrast to the observation of active out-of-sequence thrusts mapped in the eastern portions where Medlicott-Wadia Thrust and Kashmir basin faults accommodate the ongoing convergence (Vassallo et al., 2015; Shah, 2015; Shah \& Malik, 2017).

The geomorphic expressions of collisional tectonics are also preserved as intermontane basin formation and the development of drainage systems that are scattered throughout the dimensions of the orogen. The Peshawar and Kashmir intermontane basins are the two most prominent geomorphic expressions in the NW Himalaya that are oriented on either side of the HKS (Bossart et al., 1990). These preserve distinctive and tectonically controlled developmental history (Burbank \& Johnson, 1982; Burbank \& Raynolds, 1984; Shah et al., 2020). Thus, the formation and evolution of these basins are linked to each other. The drainage development has also registered these changes over the geological past, and one of the prominent river systems to have developed during the recent (>5 Ma) collisional history is the Jhelum River, which originates in Kashmir, and travels >600 km until it meets Chenab River, and finally converges with the Indus River (Fig. 1B).

\section{Methodology}

\subsection{Structural mapping using satellite data}

We have used Google terrain satellite images (Fig.1A) to map the tectonic geomorphology because the satellite data provides a broader outlook of the region, which make regional structural mapping possible and offers best freely available tools to navigate the details that are routinely difficult to record in the field because of the complexity of terrain and inaccessibility (e.g. Tapponnier \& Molnar, 1977; Nakata, 1989; Pathier et al., 2006; Avouac et al., 2006; Kaneda et al., 2008; Shah, 2015; Shah \& Malik, 2017, Shah et al., 2018b). The geomorphic mapping was achieved by manually tracking and tracing the changes in topography, drainage, geology, and geomorphology. We have mapped ridge crests (e.g. Shah, 2015; Shah \& Malik, 2017) that are extremely useful to delineate structural breaks, and often such breaks are related to faulting. The triangular facets are equally helpful and are used to map the bedding dip direction, and active faults (Shah \& Malik, 2017). The abrupt turning or deflection of drainage is also used to map the active faults and folds that have caused the changes. The relative age relationship criteria are used to constrain ages on structures, and it includes faulted Holocene basins and cross-cutting of structures. This exercise was followed by 
the examination of available seismological data that includes earthquake centroid moment tensor events supplemented with the structural, geologic (e.g. Jackson \& McKenzie, 1984; Nakata, 1989), and paleomagnetic data.

The regional scale of mapping based on the remote sensing data that we have used does not require meters of accuracy and as such satellite data provided by Google are good enough to achieve our objectives. The limitations of such data in the mapping of tectonic landforms are detailed in Shah et al. (2018b).

\subsection{Seismological and centroid moment tensor data}

The earthquake hypocenters were obtained from the National Earthquake Information Center (NEIC), and it covers a time span from 1960 to 2018 with events of magnitude >4.5 (Fig. 2). These data are plotted on the satellite image of the region to interpret and understand the distribution of earthquakes, and the pattern of active faulting. The centroid moment tensor (CMT) solutions data are extracted from the GeoMap App., which is a web-based interface for geological, geophysical and other such data. The CMT data used are sourced in the Global CMT Catalog and it covers events from Jan 1976 until July 2019 (Fig. 2B). The selected events that were used for structural analysis are shown in Figure 1B. We matched the strike and rake values with our mapped faults and used this information to create 3D illustrations to represent the brittle faulting pattern in the region and its relationship with the regional plate convergence. The earthquake structural parameters, for example, dip, dip-direction, strike and rake were used and correlated with the mapped faults in FaultKin. (Marrett \& Allmendinger, 1990), which is a competent structural geology software. Finally, we have assigned an expected centroid moment tensor solution to each of the major active faults to show how a future earthquake CMT solution would like if the earthquake occurs on the mapped fault. Paleomagnetic data from (Bossart \& Ottiger, 1989; Bossart et al., 1990) are used to interpret the geological, structural, and geomorphic mapping of the region. These data are showing the clockwise rotation of the Kashmir and anticlockwise of the Peshawar basins (Shah et al., 2020).

\section{Results and Interpretations}

\subsection{Tectonic Geomorphology}

The entire region is shown in two major rectangular regions (Fig. 1A), which are investigated in detail (Figs. 3 to 15). We have started the geomorphic investigation of the tectonic landforms in the Jhelum fault region where the evidence for left-lateral strike-slip faulting is shown by the deflected streams, which have captured lateral displacement in the rage of $<40 \mathrm{~m}$ to $>2 \mathrm{~km}$ (Fig. 3). The abrupt deflection and truncation of ridge crests is reflective of faulting, which is supplemented by the occurrence of a large triangular-shaped ridge that is delineated on the east by the southwest 
verging reverse fault, and on the west by the N-S trending Jhelum fault (Fig. $3 \mathrm{~b}$ and $3 \mathrm{c}$ ). The triangular facets and wineglass canyons are mapped on the hanging wall block of the $\sim$ NW-SE trending reverse fault. The Jhelum River flows along the fault and turns sharply $90^{\circ}$ at Tunda, Muzaffarabad (Fig. 1A). Please note the abrupt turning of the river coincides with the traces of the active reverse and strike-slip faults that interact at that location (Fig. 3), which indicates a strong structural control on the river path, and possibly on its morphology (Shah et al., 2020). The regional geological and structural map (Fig. 1B) also suggests a left-lateral offset along the trace of the JF where major geological units are juxtaposed against each other. The fault is mapped as a pure strike-slip fault in the north, and in future, if it hosts an earthquake that would possibly resemble the beachball that we have created using the structural parameters of the fault (Fig. 3D).

The southern extent of the faulting is more oblique (Fig. 4-7) with the dominance of oblique southeast verging thrusts that are associated with a small component of left-lateral strike-slip. The active faulting is evident as many faults have ruptured the surface and displaced Quaternary fluvial deposits (Figs. 4 and 5). The $\sim$ NE-SW strike of the faults is different from the similar faults that are mapped in the east of the JF and indicates rotation (Shah et al., 2020). The south plunging asymmetrical syncline marks the position where the Jhelum fault emerges (Fig. 5B), and the longest limb of the fold is parallel to the shear direction of the left-lateral and reverse fault systems. The complete disruption of the geological units confirms faulting and the relatively higher topography on its east is a reconfirmation that leftlateral displacement has occurred over the past, and it is still active. The trace of the JF is subtle as we move further south but a clear topographic break is observable at the frontal ranges where the Mangla Dam sits on the hanging wall block of the frontal thrust fault system that has been displaced by the JF (Fig. 6). The NW-SW trending sedimentary beds are rotated and faulted across the JF, which clearly demonstrates active faulting and evidence for left-lateral strike-slip related anti-clockwise block rotation on its east with asymmetrical and plunging geometries of folds that are a reflection of the large scale oblique deformation with a prominent component of left-lateral shear. The clockwise counterparts on the west are observed to have a relatively simple structural geometry (Fig. 6).

Further south the fault zone is not visible as it is buried under the sediment load from the Jhelum River. However, the river initially moves parallel to the trend of the frontal mountains before it is deflected towards the west-southwest by the emergence of the frontal anticline (Fig. 7). The young doubly plunging NE-SW trending anticline is $>40 \mathrm{~km}$ long fold, and it truncates the $\sim \mathrm{NW}$-SE trending fold-and-thrust belt in the east of JF, which indicates active faulting. The 
western termination of the fold is marked by the Jhelum River, which flows through the seemingly faulted rocks as folded rocks again emerge on the west side of the river (Fig. 1). Therefore, the trace of the JR is structurally controlled where it initially flows $\sim$ parallel to the trace of the JF followed by the deflection towards the right and parallel to the frontal fault, and then again it is deflected by the frontal fold, and eventually comes out through the frontal fold-\&thrust belt (Fig. 1). The northern extent of the JF zone coincides with the Balakot-Bagh fault (Fig. 1) that caused the moment magnitude (Mw) 7.6 Muzaferabad Earthquake in 2005 and resulted in an unfortunate loss of more than 80,000 people (Pathier et al., 2006).

We have mapped another fault (Figs. 8-10) that shows subtle evidence of left-lateral strike-slip movement and it is morphologically like the trend of the JF. The Indus River flows along the trace of it, and the geomorphic expression of faulting is very clear where rocks are dissected by the $\sim \mathrm{N}-\mathrm{S}$ trending fault. The river follows the fault for $>60 \mathrm{~km}$ in an N-S direction before turning southwest. The total strike length extends for $>100 \mathrm{~km}$ before it turns west and emerges as a reverse fault with a small component of left-lateral slip. We have named it the Tarbela fault (TB) because it runs under the Tarbela Dam (Fig. 10). The emergence of Lower Proterozoic metamorphic rocks along the track of the river clearly suggests faulting (Fig.1B). The JF and TB fault zones are around 60km apart, and the active deformation zone in between is represented by a series of $\sim$ southeast verging reverse faults that have displaced Quaternary sediment-filled basins (Fig. 11). The region is faulted, and evidence for active faults is widespread (Fig. 11). For example, the $\sim \mathrm{NW}-\mathrm{SE}$ trending dextral strike-slip faulting is based on the topographic expression where the Quaternary landforms are faulted, and the streams show lateral displacement that varies from 1-3km (Fig. 11). The $>3 \mathrm{~km}$ right-lateral bend of the Indus River coincides with the emergence of $\sim$ ENE-WSW trending fault that pierces through the trace of the TB, which indicates that it is younger and active. We think the fault is a reverse fault with a dextral component, which is based on the geomorphic expression where the upthrown block is on the north of the fault, and it seems the dip direction of the fault is $\sim$ north. The eastern termination of the fault is marked by the mountains that are not faulted, and are located above the JF zone, while as the western extent of the faulting continues for more than $100 \mathrm{~km}$, and we think it is a major fault that possibly runs under the Peshawar basin.

\section{Active faulting in the Salt Range region}


The Salt Range thrust bounds a >100km long antiform that resembles anticline as north dipping limb is well exposed and easy to map but the southern limb is delineated by the Salt Range thrust fault. The fold is plunging east and $>90 \mathrm{~km}$ long active fault delimits it and pierces through it (Figs. 12 and 13). This fault has been mapped by Shah et al. (2020), and to the best of our knowledge, we do not know any other source that has named the fault. For example, the structural map produced in Jaumé \& Lillie (1988) have also mapped fault but it has not been named. We have therefore named it as the Naalah Ghaan fault because the fault has deflected the Naalah (stream) Ghaan, which has recorded $\sim 4 \mathrm{~km}$ leftlateral offset (Fig. 12). However, the deflection is not observed at other nearby streams, and structures, which means that the river has followed the fault and deflected with it, rather than displaced by the fault (Fig. 12). The fault bounds a fold, and overall 3 prominent anticlinal folds appear at the southeastern region of the Jhelum fault (Fig. 12), and their arrangement fits the left-lateral en-echelon folding pattern, and therefore, we have interpreted the folding as a result of the oblique left-lateral shearing: shearing accompanied by thrusting, which is related to the oblique plate convergence. The folds do not continue east and are truncated by the Jhelum fault, which seems to have caused the rotation (Jaumé \& Lillie, 1988; Shah et al., 2020) in the region.

The Salt Range has an impressively visible dextral offset between the Jhelum and the Kalabagh faults, and we have mapped faults there that truncate the range and have caused the dextral strike-slip displacement (Fig. 13). The overall faulting pattern also resembles an en-echelon style and seems to be controlled by the major dextral strike-slip system, the Kalabagh fault. The oblique convergence between India and Asia has forced this region to form an array of oblique faults that are sandwiched between the Chaman and the Jhelum faults, and broadly the region has a strong $\sim$ southwest tectonic transport that is facilitated by the fault and fold systems. This is also shown by the tectonic topography of the nearby regions (Figs. 14 and 15) where a range of tectonic features are mapped and clearly suggest that active reverse and strike-slip faults dominate the region. The stunning geomorphic expression of the dextral strike-slip fault, the Bain Darra fault zone, is shown in Fig. 15 where a southeast plunging anticline is ruptured by the fault. The Marwat and Khishor Ranges seem to have been dextrally displaced along the fault where the ranges are abruptly truncated by the fault. The fault marks the southwestern border of the ranges and the eastern border seems to be delimited by another active fault, which fits a sinistral strike-slip faulting pattern where the Surghar Ranges are displaced. Such a fault exists, and we have named it the Surghar Range fault, and the left-lateral displacement of the lithological boundaries is measured to be $>1 \mathrm{~km}$ at the southern ridge. The prominent $\sim 2 \mathrm{~km}$ dextral bend of the Kurram River seems misleading 
as the fault is left-lateral and not dextral. The eastern extent of the Surghar Range is bounded by the Kalabagh fault zone, which has been previously mapped by many researchers (references herein).

\section{Drainage maps}

The drainage map of the region shows prominent development drainage patterns that are largely a reflection of bedrock geology and structures. The parallel drainage pattern is mapped in the foreland basin, which is morphologically similar to the drainage networks observed in the Potwar regions. It suggests that that parallel drainage networks have developed before the emergence of the Himalayan frontal systems, and once the frontal fault systems created the topography the drainage was deflected, isolated, and separated from the foreland basin. The rivers are shown in blue colour (Figs. 1 and 2) are the major drainages (e.g. Jhelum, Indus) and are flowing towards the southwest, which is a direct reflection of the oblique tectonic convergence (James et al., 1993). The collision has created tectonic topography with a prominently developed drainage divided between rivers flowing western and east and that suggests that drainage development is a direct consequence of oblique convergence and strike-slip deflection is remarkably preserved by many of the smaller and larger streams (e.g. Jhelum, Indus etc.). The older rocks are exposed along the Indus river, which clearly indicates that it has carved deep within the bedrock geology, which was facilitated by the faulting (this study).

\section{Seismological and centroid moment tensor data}

The earthquake data show evidence for active faulting in the region with a large clustering around the epicentre of 2005 quake (Fig. 2B). The earthquake centroid moment tensor data broadly show transpression with left-lateral strike events associated with reverse faulting (Fig. $2 \mathrm{C}$ ). The dominance of $\sim \mathrm{NW}-\mathrm{SE}$ reverse faulting events is mainly related to the major earthquake that occurred in 2005 (Fig. 16A). There is evidence for strike-slip faulting, which is related to the active faults that we have mapped here (Figs. 3 to 15). The paleomagnetic data from Bossart \& Ottiger (1989) are used (Fig. 16B) to interpret the evidence for rotation on either side of the JF zone, where clockwise rotation of the eastern portions (e.g. Kashmir basin) is clearly supported by the data. Similarly, the anti-clockwise rotation of the western portions (e.g. Peshawar basin) is also supported by the data (Fig. 16).

\section{Discussion}

\subsection{Oblique tectonic convergence via strike-slip, reverse and thrust faulting}

The works presented here indicates that the strike-slip along with a reverse and thrust faulting is common in the western portion of the Hazar-Kashmir syntaxis, which is shown by a large number of tectonically active geomorphic 
features and earthquakes (Figs. 3-15). The left-lateral Jhelum and the Tarbela faults are morphologically similar and are separated by $<50 \mathrm{~km}$. The pattern of active faulting is systematic and fault interaction seems to play a key role in accommodating active deformation in the region. The Potwar region is limited by the left-lateral Jhelum fault in the east, which is not observable at the north of the HKS where the older geological units are exposed, which indicates that reverse faults are truncating the trace of the Jhelum fault and limiting its extent in the north. The western boundary of the Potwar region is marked by the dextral strike-slip the Kotabagh fault system but the fault is not a major discontinuity and reflects a locally developed strike-slip fault that accommodates some portions of the regional oblique convergence between India and Eurasia.

Regionally, the active deformation occupies the portions between the Chaman and the Jhelum fault systems, which are both left-lateral strike-slip faults. The former is a major fault between Pakistan and Afghanistan and reflects the western boundary of the two lithospheric plates (Lawrence \& Yeats, 1979). The fault accommodates a portion of the oblique plate convergence budget where the India plate moves at $\sim 36 \mathrm{~mm} / \mathrm{yr}$ with respect to the Eurasia plate near $30^{\circ} \mathrm{N}$ (DeMets et al., 2010). The active geomorphic landforms and their influence on the drainage pattern suggest that the ongoing plate scale deformation is heterogeneously distributed on various fault system in the west of the HKS, which has not to be quantified yet (e.g. Cortés-Aranda et al., 2017; Shah et al., 2020; Ghani et al., 2020). This is remarkably different from the deformation observed in the eastern portion of the HKS where the Himalayan frontal thrust faults accommodate about half of the plate convergence and the deformation is not distributed over a large region as is observed in the Pakistan and Afghanistan regions (Vassallo et al., 2015; Bilham, 2019). Therefore, the seismic hazard in the western portion of the HKS that includes the regions between the Jhelum and the Chaman fault system should be less worrying as compared to the portion in the east that includes regions between the Jhelum fault and the Sagaing Fault (Fig. 17). We have suggested it based on the active tectonic landforms, their pattern, distribution, and plate convergence budget, which indicates that regional plate deformation is accommodated by a large network (basically a family) of faults that mainly includes strike-slip, reverse and thrust faults in the study area that are spread and distributed over a large region. This does not mean that the active faults will not produce a major earthquake in the future but suggests that deformation is more distributed in western regions and should be expected to release the strain on multiple faults, rather than on a few major faults as is the case in the east. 


\subsection{Earthquake hazards and active out of sequence faulting}

The devastation caused by the earthquake of 2005 in Muzaffarabad and eastern Kashmir region raised questions not only on the damage but also on the occurrence of earthquake hazards in the interior portions of the Himalayas (Pathier et al., 2006; Shah \& Malik, 2017). The earthquake surface rupture was mapped for $\sim 80 \mathrm{~km}$ and it ruptured the HazaraKashmir Syntaxis and has reactivated the Tanda and the Muzaffarabad faults (Shah et al., 2020). This event also caused considerable reactivation of the scientific discussion on earthquake hazards in the hinterland region, which were previously largely ignored because the traditional wisdom was to watch the frontal Himalayan fault system that has produced many large magnitude earthquakes in the past and would continue in future (e.g. Bilham, 2019). Our work adds more data on the active faults in the interior regions (Shah et al., 2020, and this study), and we have demonstrated the evidence for strike-slip, reverse, and thrust faults in the regions between the Chaman and the Jhelum fault systems. Previous works (e.g. Cortés-Aranda et al., 2017) have suggested that active deformation within the western portion of the HKS are accommodated on the four major faults: the Kalabagh Fault, the Salt Range Thrust, the Mahesian Anticline, and the Jhelum Fault, and our work shows that apart from the listed structures there are other major faults and folds that are active. We suggest that deformation is primarily limited between the Chaman and the Jhelum fault, which forms the sides of a tectonically formed diamond-shaped deformation box that has Salt-Range Thrust in front and the Main Boundary Thrust at the back (Fig. 17).

The tectonic geomorphologic and earthquake centroid moment tensor data suggest that active deformation is not just limited between the Main boundary fault and the Himalayan frontal fault systems but extends further north of the MBT, which clearly questions the traditional view of the in-sequence faulting where active faults are expected to follow a foreland directed chronological sequence (Morley, 1988). Therefore, we suggest that out of sequence faulting in a typical collisional orogen is not an exception but a role. It seems that during a typical collisional mountain building process the megathrust fault system absorbs most of the plate convergence, and when the hanging wall grows and accumulate significant mass because of the thrusting the reactivation of the fault becomes harder, and therefore the strain hardening process preferentially selects new regions where faults nucleate. And as time progresses the faults becomes younger towards the frontal mountains. However, new faults could rupture in the interior regions as well if the conditions permit such a process, and we think that is what is happening in a typical collisional zone where out of sequence faults form or reactive because the conditions allow such a process to proceed. The geomorphic and seismological data suggest that such conditions are present in the NW Himalaya, and potentially in the western 
portions of the HKS. Therefore, we think the active faulting in the region will continue but it may not produce recurring larger earthquakes as are expected in the eastern Himalayas (Bilham, 2019) because the deformation is partitioned in into a wider zone as compared to the region in the east of the HKS where the deformation is limited within the narrow width of the frontal portions plus the absence of salt makes it easier to accumulate strain for a longer duration (Shah et al., 2020).

\subsection{The Jhelum fault system: a major discontinuity in the NW Himalaya}

The left-lateral strike-slip, the Jhelum fault, demarcates the eastern portion of the Potwar Plateau-Salt Range region in Pakistan (Shah et al., 2020) and the tectonic geomorphology of the region indicates dominance of active left-lateral strike-slip and $\sim$ southeast verging reverse and thrust faults (Figs. 3 to 15 ). The JF is a major fault system that extends for $>120 \mathrm{~km}$ and has also displaced some portion of the frontal fault system (Figs. 3 to 7), which indicates that it is tectonically active (Shah et al., 2020, and this study). It is suggested by tectonic geomorphology where the southern termination of the fault is mapped as inferred because it is buried under sediments that are largely transported by the Jhelum River. The clear topographic break at the frontal portions that run under the Mangla Dam is related to the Himalayan Frontal fault system (Fig. 6) that has been left-laterally displaced for a few km. The indicates that both frontal, as well as the Jhelum fault zones, are active, and since the dam sits on these faults, therefore, it could cause considerable damage in a future medium to large magnitude earthquake if proper seismic hazard investigation is not put in place. The dense population (Fig. 16A) and unregulated urbanization in the region add more constraints on the safety of people (Shah et al., 2018a). This was observed during and after the 2005 Kashmir event (Fig. 16A) where large damage was mapped, and it is reflected in the available ShakeMaps from USGS, which provide a quick and reliable guide to map the ground shaking during an earthquake. The PGA (peak ground acceleration) shake map (Fig. 16A) shows high levels that had reached the Kashmir basin in the east, and the Peshawar basin in the west. The incidents of liquefaction related to this event were reported as far as the Jammu region (Malik et al., 2007).

The northern extent of the JF zone dies under mountains, and the 2005 earthquake-related propagation of rupture suggested its abrupt termination at the hairpin turn of the MBT (Avouac et al., 2006; Fig. 16A). The finite fault derived from the earthquake data (Fig. 16A) shows that the earthquake rupture had propagated towards the southeast and not northwest, where it was terminated. This suggests strong structural control at depth, and our work suggests that JF interacts with Balakot-Bagh fault at the Tunda where the abrupt turn of the Jhelum River is observed (Fig. 3). This has created a triangular ridge structure (Fig. 3) and the northern limit of the JF terminates under mountains but 
reappears on the west as a new fault, the Tarbela fault, which is located towards the east of the JF, and both are active. This suggests that active faulting in the regions that are located towards the west of the HKS is dominated by $\sim \mathrm{N}-\mathrm{S}$ trending strike-slip faults, which usually change strike, and become more oblique towards the west and southwest

(Figs. 3 to 15). This means that the active faulting is a typical outcome of transpression where regional oblique plate convergence between India and Eurasia is dominantly absorbed by oblique faulting that involves left-lateral strikeslip and reverse faults. The overall tectonic transport is westward in regions that are located west of the HKS and this is facilitated by the dominance of left-lateral strike-slip and reverse fault systems, which is in contrast to the active tectonic transport observed in its eastern portions. The eastward tectonic transport in the eastern, central and western Himalayan orogenic system is mainly facilitated by strike-slip and normal faulting in the interior regions and via reverse faulting in the frontal portions (Fig. 1).

The existence of the JF zone, and its coincidence at the Hazara-Kashmir Syntaxis, which marks the location where the structural trend of the major Himalayan fold-and-thrust belt abruptly turns, and it contains an overlapping of thrust systems (Bossart \& Ottiger, 1989). This suggests that JF is a major structural discontinuity that has contributed to the structural complexity that is observed at the syntax, and it is this fault that has contributed to the formation of the HKS. The topographic expression on either side of the fault is markedly different as can be observed on the topographic maps where eastern portions are higher compared to the western portions. This could be explained by the uplift where fault resists and build topography, but this is not similarly expressed in the west where salt could be playing a major role (e.g. Burbank \& Beck, 1989). The low resistance of evaporates could facilitate displacement and transport of material with little role for brittle failure via faulting. The paleomagnetic data from Bossart \& Ottiger (1989) suggests evidence for rotation on either side of the JF zone (Fig. 16B), where clockwise rotation of the eastern portions (e.g. Kashmir basin) and anti-clockwise rotation of the western portions (e.g. Peshawar basin) is supported by the data (Fig. 16B). This indicates that the JF zone has formed after the Main boundary fault system, and before the Main Himalayan frontal thrust. The dominance of strike-slip movement in the north and dip-slip in the south further indicates left-lateral rotation, which could be related to the clockwise rotation of the plate convergence of the northern India plate margin.

\section{Conclusions}

The active geomorphic features that we have mapped clearly suggest that active collisional deformation related to the ongoing convergence between the lithospheric plates of India and Eurasia is distributed preferentially on strike-slip, 
reverse, and thrust faults. The faults are interacting in the region between the Chaman and Jhelum fault systems Jhelum faults, where the northern limit is restricted by the Main boundary fault, and the southern by the Salt-Range thrust. Therefore, the active deformation in the region is restricted in a tectonically formed diamond-shaped box-like structure where the sides at the east and west are limited by the strike-slip faults, while the north and south borders of the box are limited by the thrust faults. The Chaman fault, which is a left-lateral strike-slip fault system seems to predominantly control the shear on the box and therefore acts as a major fault in the west. Therefore, the existence of dominantly active left-lateral strike-slip along with reverse faults in eastern Pakistan indicates tectonic transpression, which is largely a reflection of the ongoing oblique convergence between India and Eurasia. The faults are active, and actively participating in the ongoing collision, but relatively less strain release during the past decades by the occurrence of major earthquakes in the region indicates that the faults are probably slipping aseismically, and that could be related to the presence of salt at depth. The region with salt at the base would not accumulate much strain, and therefore there are more chances that these regions will not build topography, which is usually an outcome of the interaction of tectonic plates where resistance builds tectonic topography. The absence of salt will allow much greater topographical developments while an absence of salt will hamper it, and therefore the topography will be subdued.

\section{Conflict of Interest Statement}

On behalf of all authors, the corresponding author states that there is no conflict of interest.

\section{Acknowledgements}

The authors are highly thankful to Dr. Sheeba Khawaja for correcting and improving English.

\section{References}

Aitchison, J. C., Ali, J. R., \& Davis, A. M. (2007). When and where did India and Asia collide?. Journal of Geophysical Research: Solid Earth, 112(B5).

An, W., Hu, X., Garzanti, E., Wang, J.G. \& Liu, Q., 2021. New precise dating of the India-Asia collision in the Tibetan Himalaya at 61 Ma. Geophysical Research Letters, e2020GL090641.

Aug, C.F.F., (1907). An Exploration of the Mustagh Pass in the Karakoram Himalayas. Geographical Journal, 630643. 
Avouac, J., Ayoub, F., Leprince, S., Konca, O. \& Helmberger, D., 2006. The 2005, Mw 7.6 Kashmir earthquake: Subpixel correlation of ASTER images and seismic waveforms analysis. Earth and Planetary Science Letters, 249(3-4), 514-528.

Avouac, J.P., 2007. Dynamic Processes in Extensional and Compressional Settings - Mountain Building: From Earthquakes to Geological Deformation, Treatise on Geophysics, 6, 377 - 439.

Baig, M.S. \& Lawrence, R.D., 1987. Precambrian to Early Paleozoic orogenesis in the Himalaya. Kashmir Journal of Geology, 5, 1-22.

Bilham, R., 2019. Himalayan earthquakes: a review of historical seismicity and early 21st century slip potential. Geological Society, London, Special Publications, 483(1), 423-482.

Bossart, P., Dietrich, D., Greco, A., Ottiger, R. \& Ramsay, J., 1988. The tectonic structure of the Hazara-Kashmir Syntaxis, southern Himalayas, Pakistan. Tectonics, 7(2), 273-297.

Bossart, P. \& Ottiger, R., 1989. Rocks of the Murree formation in Northern Pakistan: Indicators of a descending foreland basin of late Paleocene to middle Eocene age. Eclogae Geologicae Helvetiae, 82(1), 133-165.

Bossart, P., Ottiger, R. \& Heller, F., 1990. Rock magnetic properties and structural development in the core of the Hazara-Kashmir Syntaxis, NE Pakistan. Tectonics, 9(1), 103-121.

Burbank, D. \& Johnson, G., 1982. Intermontane-basin development in the past 4 Myr in the north-west Himalaya. Nature, 298(5873), 432-436.

Burbank, D. \& Reynolds, R., 1984. Sequential late Cenozoic structural disruption of the northern Himalayan foredeep. Nature, 311(5982), 114-118.

Burbank, D., Leland, J., Fielding, E., Anderson, R., Brozovic, N., Reid, M. \& Duncan, C., 1996. Bedrock incision, rock uplift and threshold hillslopes in the northwestern Himalayas. Nature, 379(6565), 505-510.

Burbank, D.W. \& Beck, R.A., 1989. Early Pliocene uplift of the Salt Range; temporal constraints on thrust wedge development, northwest Himalaya, Pakistan. In Tectonics of the western Himalayas. Geological Society of America, $232,113-128$.

Butler, R.W., Coward, M.P., Harwood, G.M. \& Knipe, R.J., 1987. Salt control on thrust geometry, structural style and gravitational collapse along the Himalayan mountain front in the Salt Range of northern Pakistan. In Dynamical geology of salt and related structures. Academic Press, 339-418. 
Butler, R.W.H., 2019. Tectonic evolution of the Himalayan syntaxes: the view from Nanga Parbat, Himalayan Tectonics: A Modern Synthesis, P. J. Treloar, M. P. Searle.

Catlos, E.J., Harrison, T.M., Kohn, M.J., Grove, M., Ryerson, F.J., Manning, C.E. \& Upreti, B.N., 2001. Geochronologic and thermobarometric constraints on the evolution of the Main Central Thrust, central Nepal Himalaya. Journal of Geophysical Research: Solid Earth, 106(8), 16177-16204.

Chen, L. \& Khan, S.D., 2010. InSAR observation of the strike-slip faults in the northwest Himalayan frontal thrust system. Geosphere, 6(5), 731-736.

Cortés-Aranda, J., Mugnier, J.L., Jouanne, F., Vassallo, R., Carcaillet, J. \& Awan, A.A., 2017. Holocene shortening rates and seismic hazard assessment for the frontal Potwar Plateau, NW Himalaya of Pakistan: Insights from 10Be concentrations on fluvial terraces of the Mahesian Anticline. Quaternary International, 462, 75-89.

DeMets, C., Gordon, R.G. \& Argus, D.F., 2010. Geologically current plate motions, Geophysical Journal International, 181(1).

Dipietro, J.A. \& Pogue, K.R., 2004. Tectonostratigraphic subdivisions of the Himalaya: A view from the west.

Tectonics, 23.

Ghani, H., Zeilinger, G., Sobel, E.R. \& Heidarzadeh, G., 2018. Structural variation within the Himalayan fold and thrust belt: A case study from the Kohat-Potwar Fold Thrust Belt of Pakistan. Journal of Structural Geology, 116, 3446.

Ghani, H., Sobel, E.R., Zeilinger, G., Glodny, J., Zapata, S. \& Irum, I., 2020. Palaeozoic and Pliocene tectonic evolution of the Salt Range constrained by low-temperature thermochronology. Terra Nova, 1-13.

Jackson, J. \& McKenzie, D., 1984. Active tectonics of the Alpine--Himalayan Belt between western Turkey and Pakistan. Geophysical Journal International, 77(1), 185-264.

James, W.M., Ahmad, H. \& Robert, S.Y., 1993. The Main Boundary Thrust and propagation of deformation into the foreland fold-and-thrust belt in northern Pakistan near the Indus River, Geological Society, London, Special Publications, 1, 581-588.

Jaumé, S.C. \& Robert, J.L., 1988. Mechanics of the Salt Range-Potwar Plateau, Pakistan: A fold-and-thrust belt underlain by evaporites. Tectonics, 7(1), 57-71.

Kaneda, H., Nakata, T., Tsutsumi, H., Kondo, H., Sugito, N., Awata, Y., Akhtar, S., Majid, A., Khattak, W., Awan, A., Yeats, R., Hussain, A., Ashraf, M., Wesnousky, S. \& Kausar, A., 2008. Surface Rupture of the 2005 Kashmir, 
Pakistan, Earthquake and Its Active Tectonic Implications. Bulletin of the Seismological Society of America, 98(2), $521-557$.

Lavé, J. \& Avouac, J.P., 2000. Active folding of fluvial terraces across the Siwaliks Hills, Himalayas of central Nepal. Journal of Geophysical Research, 105.

Lavé, J. \& Avouac, J., 2001. Fluvial incision and tectonic uplift across the Himalayas of central Nepal. Journal of Geophysical Research-Solid Earth, 106(11).

Lawrence, R.D. \& Yeats, R.S., 1979. Geological reconnaissance of the Chaman fault in Pakistan, in Geodynamics of Pakistan, edited by A. Farah and K. A. DeJong. Geological Survey of Pakistan, 351-357.

Le Fort, P., 1975. Himalayas: the collided range. Present knowledge of the continental arc. American Journal of Science, 275(1), 1-44.

Malik, J.N., Sahoo, A.K., Shah, A.A., Rawat, A. \& Chaturvedi, A., 2007. Farthest recorded liquefaction around Jammu caused by 8 October, 2005 Muzaffarabad earthquake of Mw= 7.6 Journal of Geological Society of India, 69(1), 39.

Marrett, R. \& Allmendinger, R.W., 1990. Kinematic analysis of fault-slip data. Journal of Structural Geology, 12(8), 973-986.

McDougall, J.W. \& Hussain, A., 1991. Fold and thrust propagation in the western Himalaya based on a balanced cross section of the Surghar Range and Kohat Plateau, Pakistan. AAPG bulletin, 75(3), 463-478.

Meigs, A.J., Burbank, D.W. \& Beck, R.A., 1995. Middle-late Miocene (> 10 Ma) formation of the Main Boundary thrust in the western Himalaya. Geology, 23(5), 423-426.

Molnar, P. \& Tapponnier, P., 1975. Cenozoic Tectonics of Asia: Effects of a Continental Collision: Features of recent continental tectonics in Asia can be interpreted as results of the India-Eurasia collision. Science, 189(4201), 419.

Morley, C.K., 1988. Out-of-sequence thrusts. Tectonics, 7(3), 539-561.

Nakata, T., 1989. Active faults of the Himalaya of India and Nepal. Geological Society of America Special Papers, $232,243-264$.

Ni, J. \& Barazangi, M., 1984. Seismotectonics of the Himalayan collision zone: Geometry of the underthrusting Indian plate beneath the Himalaya. Journal of Geophysical Research: Solid Earth, 89(2), 1147-1163.

Pathier, E., Fielding, E., Wright, T., Walker, R., Parsons, B. \& Hensley, S., 2006. Displacement field and slip distribution of the 2005 Kashmir earthquake from SAR imagery. Geophysical Research Letters, 33(20). 
Powell, C.M. \& Conaghan, P.J., 1973. Plate tectonics and the Himalayas. Earth and Planetary Science Letters, 20(1), $1-12$.

Qadir, A. \& Shah A.A., 2020. Lessons from online teaching, learning and research communications due to COVID19 related lockdown. Retrieved from https://zif.hypotheses.org/773.

Ruleman, C., Crone, A., Machette, M., Haller, K. \& Rukstales K., 2007. Geological Survey, VA D 1: 20070000 Map and Database of Probable and Possible Quaternary Faults in Afghanistan Rep. United States Geological Survey.

Ryan, W.B.F., S.M. Carbotte, J.O. Coplan, S. O'Hara, A. Melkonian, R. Arko, R.A. Weissel, V. Ferrini, A. Goodwillie, F. Nitsche, J. Bonczkowski, and R. Zemsky (2009), Global Multi-Resolution Topography synthesis, Geochem. Geophys. Geosyst., 10, Q03014, doi:10.1029/2008GC002332.

Shah, A.A., 2015. Kashmir basin fault and its tectonic significance in NW Himalaya, Jammu and Kashmir, India. International Journal of Earth Sciences, 104(7), 1901-1906.

Shah, A.A. \& Malik, J.N., 2017. Four major unknown active faults identified, using satellite data, in India and Pakistan portions of NW Himalaya. Natural Hazards, 88(3), 1845-1865.

Shah, A., Khwaja, S., Shah, B., Reduan, Q. \& Jawi, Z., 2018a. Living with Earthquake and Flood Hazards in Jammu and Kashmir, NW Himalaya. Frontiers in Earth Science, 6.

Shah, A.A., Zhafri, M.N., Delson, J. \& Navakanesh, B. 2018b. Major strike-slip faults identified using satellite data in central Borneo, SE Asia. Geosciences, 8(5), 156.

Shah, A.A., Abd Manan, N., Aliudin, N.A.B., Cahyaningsih, C., Batmanathan, N.M. \& Malik, J.N., 2020. Formation, rotation, and present-day configuration of Kashmir and Peshawar basins in NW Himalaya. Frontiers in Earth Science, 8,441 .

Swan, L.W., 1961. The ecology of the high Himalayas. Scientific American, 205(4), 68-79.

Tapponnier, P. \& Molnar, P., 1977. Active faulting and tectonics in China. Journal of Geophysical Research, 82(20), 2905-2930.

Tapponnier, P., Mattauer, M., Proust, F. \& Cassaigneau, C., 1981. Mesozoic ophiolites, sutures, and large-sale tectonic moevements in Afghanistan. Earth and Planetary Science Letters, 52, 355-371. 
Vassallo, R., Mugnier, J., Vignon, V., Malik, M., Jayangonda Perumal, R., Srivastava, P., Jouanne, F. \& Carcaillet, J., 2015. Distribution of the Late-Quaternary deformation in Northwestern Himalaya. Earth and Planetary Science Letters, 411, 241-252.

Wang, E. \& Burchfiel, B.C., 1997. Interpretation of Cenozoic tectonics in the right-lateral accommodation zone between the Ailao Shan shear zone and the eastern Himalayan syntaxis. International Geology Review, 39, $191-219$. Yeats, R.S. \& Lillie, R.J., 1991. Contemporary Tectonics of the Himalayan Frontal Fault System - Folds, Blind Thrusts and the 1905 Kangra Earthquake. Journal of Structural Geology, 13(2), 215-225.

Yin, A. \& Harrison, T., 2000. Geologic Evolution of the Himalayan-Tibetan Orogen. Annual Review of Earth and Planetary Sciences, 28(1), 211-280.

Yin, A., 2006. Cenozoic tectonic evolution of the Himalayan orogen as constrained by along-strike variation of structural geometry, exhumation history, and foreland sedimentation. Earth-Science Reviews, 76(1-2), 1-131.

\section{Figure Captions and Figures:}

Fig. 1. The map on the top shows the location of the study area on the Google terrain image, and the tectonic and geological setting of the region is shown in the bottom map (Dipietro and Pogue, 2004). The major rivers are also plotted on the map to highlight the structural control on the orientation of streams (read the text for details).

Fig. 2. (A) Some of the major active faults are highlighted to demonstrate that oblique plate convergence between India-Eurasia is mainly absorbed on the thrust and strike-slip faults. The rectangular region is the study area. (B) The earthquakes are plotted on the 30m shutter radar topography, which shows a large clustering of shallow seismicity near the epicentre of 2005 Kashmir (northwestern cluster) and 1905 Kangra (southeastern cluster) earthquakes. The earthquake centroid moment tensor events are also plotted on the topographic image (Fig. 1B) that were obtained from the GeoMap. App. (Ryan et al., 2009, http://www.geomapapp.org), which is an open-source software application for geological and geophysical uses. The dominance of $\sim \mathrm{NW}-\mathrm{SE}$ trending reverse and thrust faults in the eastern portions is in contrast from the $\sim \mathrm{NE}-\mathrm{SW}$ trending reverse, thrust, and strike-slip faults in the western portions, and it reflects rotation of the major Himalayan structures (see Fig. 1 for changes that are registered in geology and structures).

Fig. 3. The uninterpreted Google terrain image on top (A) is interpreted below (B). The evidence for active tectonics is mapped and shown as structural breaks with truncations of geological layers, deflections of river streams, and topographic breaks. The left-lateral strike-slip faulting is registered in the topography where ridges are offset, and 
drainage deflection is also observed. (C) The 3D illustration shows the trace of the left-lateral strike-slip Jhelum fault with a small reverse component. The expected fault plane solution is shown for the JF (D).

Fig. 4. The uninterpreted Google terrain image on the top (A) is interpreted below (B). The evidence for active faults is mapped where the $\sim \mathrm{NE}-\mathrm{SW}$ trending oblique reverse faults are dominant in the region, and these show a small component of left-lateral strike-slip faulting, which is registered in the topography where ridges are offset, and drainage deflection is also observed. (C) The 3D illustration shows the map and cross-sectional view of the faults (subsurface faulting is not to be scaled and it is only representative and not accurate). The expected fault plane solution is shown for a fault (D), and similar solutions are expected on the other mapped fault traces.

Fig. 5. The uninterpreted Google terrain image on the top (A) is interpreted below (B). The structural mapping reveals the existence of an asymmetrical syncline that has a longer limb parallel to the surface trace of the mapped reverse faults, and it sharply curls at the JF zone, which indicates a strong structural control on the formation of the fold. (C) The 3D illustration shows the trace of the major reverse fault with a possible component of the left-lateral strike-slip movement. The expected fault plane solution is shown for the reverse fault that dips $\sim$ NW (Fig. 5D).

Fig. 6. The uninterpreted Google terrain image on the top (A) is interpreted below (B). The eye-catching structural changes are observed at the structural transition zone that coincides with our mapped trace of JF. The $\sim$ south to southwest vergence of the reverse faults in the east of the JF is strikingly different from the east to southeast vergence of the reverse faults in the west (see Fig. 12 for details on this).

Fig. 7. The uninterpreted Google terrain image on the top (A) is interpreted below (B). The doubly plunging $\sim$ NE-SW trending anticlinal structure is mapped to be bordered by a major frontal thrust fault. The Jhelum River is deflected by the appearance of the anticline and indicates a much younger history of the deflection, which coincides with the formation of the Himalayan Frontal Thrust system.

Fig. 8. The uninterpreted Google terrain image on the top (A) is interpreted below (B). The clear evidence for structural breaks is mapped. The $\sim \mathrm{N}-\mathrm{S}$ trending strike-slip faulting is registered in the topography where ridges are offset, and drainage deflection is also observed but the slip is not clear, and we think it is a left-lateral strike-slip fault. (C) The 3D illustration shows the trace of the left-lateral strike-slip Tarbela fault, with a small reverse component. The expected fault plane solution is shown for the fault (D).

Fig. 9. The uninterpreted Google terrain image on the top (A) is interpreted below (B). The clear evidence for structural breaks is mapped. The $\sim \mathrm{N}-\mathrm{S}$ trending strike-slip faulting is registered in the topography where ridges are offset, and 
drainage deflection is also observed. The $\sim \mathrm{NE}-\mathrm{SW}$ trending reverse faults is also mapped that seems to have a small component of left-lateral offset. (C) The 3D illustration shows the trace of the left-lateral strike-slip Tarbela fault, with a small reverse component. The expected earthquake moment tensor is shown for the fault (D).

Fig. 10. The uninterpreted Google terrain image on the top (A) is interpreted below (B). Clear evidence for multiple structural breaks is mapped. The $\sim \mathrm{N}-\mathrm{S}$ trending strike-slip faulting is registered in the topography where ridges are offset, and drainage deflection is also observed, and this is the continuation of the Tarbela fault zone, where the leftlateral offset is not that clear but the narrow fault zone suggests strike-slip fault and we think it is a left-lateral strikeslip. Note the construction of Tarbela Dam on the active faults. (C) The 3D illustration shows the trace of the oblique fault that has a small reverse component. The expected earthquake moment tensor solution is shown for the major fault (D).

Fig. 11. The uninterpreted Google terrain image on the top (A) is interpreted below (B). The clear evidence for structural breaks is mapped. The $\sim \mathrm{NW}-\mathrm{SE}$ trending dextral strike-slip faulting is registered in the topography where ridges, drainage streams, and $\sim$ NE-SE trending reverse faults are offset across the trace of the dextral fault. The 3D illustration shows the trace of the fault zone (C). The expected earthquake moment tensor solution is shown for the major reverse faults (D).

Fig. 12. The uninterpreted Google terrain image on the top (A) is interpreted below (B). The clear evidence for active faulting is shown, which is reflected by the occurrence of folds and faults. The three $\sim \mathrm{NE}-\mathrm{SW}$ oriented anticlines are mapped, and these are interpreted as a typical result of the en-echelon pattern that is related to the oblique plate tectonic convergence between India and Eurasia that has a strong left-lateral shear in the east.

Fig. 13. The uninterpreted Google terrain image on the top (A) is interpreted below (B). The clear evidence for active faulting is shown where the faults have pierced the Salt Range Thrust system, and it is reflected by the occurrence of folds and faults. We have named Khairpur, Sehti, and Dheri Aja faults because these are exposed in those places.

Fig. 14. The uninterpreted Google terrain image on the top (A) is interpreted below (B). The clear evidence for active faulting is shown where the Salt Range Thrust, Surghar Range fault, and Kalabagh fault zones are shown. The active faults are in the north as well, and extend much further, which clearly indicates that these faults are not restricted to the frontal zones. 
Fig. 15. The uninterpreted Google terrain image on the top (A) is interpreted below (B). The clear evidence for active faulting is shown where the dextral strike-slip fault, the Bain Darra fault zone, is mapped. The right-lateral offset is registered by the river offset that is $>2 \mathrm{~km}$. The fault zone pierces through a SE plunging anticline that has been displaced by the fault.

Fig. 16A. The historical seismicity, peak ground acceleration (PGA) contours related to the 2005 Kashmir earthquake along with population density and finite fault rupture are shown. These data are obtained from USGS (see text for details). The structural map of the NW Himalaya along with paleomagnetic data are shown (16B). These data support the rotation of major lithological boundaries and structures across the trace of HKS, which is revealed from the previously published structural and geological mapping data and the tectonic geomorphology (this study).

Fig. 17. The active faults and sutures are shown on the shutter radar topography map that has $30 \mathrm{~m}$ resolution (the fault and sutures are sourced in Molnar and Tapponnier,1975, Tapponnier et al., 1981; Nakata, 1989; Lillie and Yeats, 1991; Wang and Burchfiel, 1997; Lave and Avouac, 2000, 2001 and Ruleman et al., 2007. The focal plane solution was acquired from United States Geological Survey, and the geodetic data are from Jouanne et al (2020). The major streams are shown, which are extracted using shutter radar topography.

Fig. 18. The 3D tectonic map is shown to argue that the tectonic of the study area reflects the oblique plate convergence between India and Eurasia. It forms a tectonic box where the active left-lateral strike-slip fault, the Jhelum fault forms the eastern boundary, and the dextral strike-slip fault, Kalabagh fault, forms the western boundary. The sides of the box are formed by the Salt Range Thrust and the Tarbela fault. Regionally, the study area is an active deformation zone that forms the main body of the box, which is limited by the Main Himalayan Thrust in the north, and Main Boundary thrust in the south, with the Chaman and the Jhelum faults delimiting its sides. 

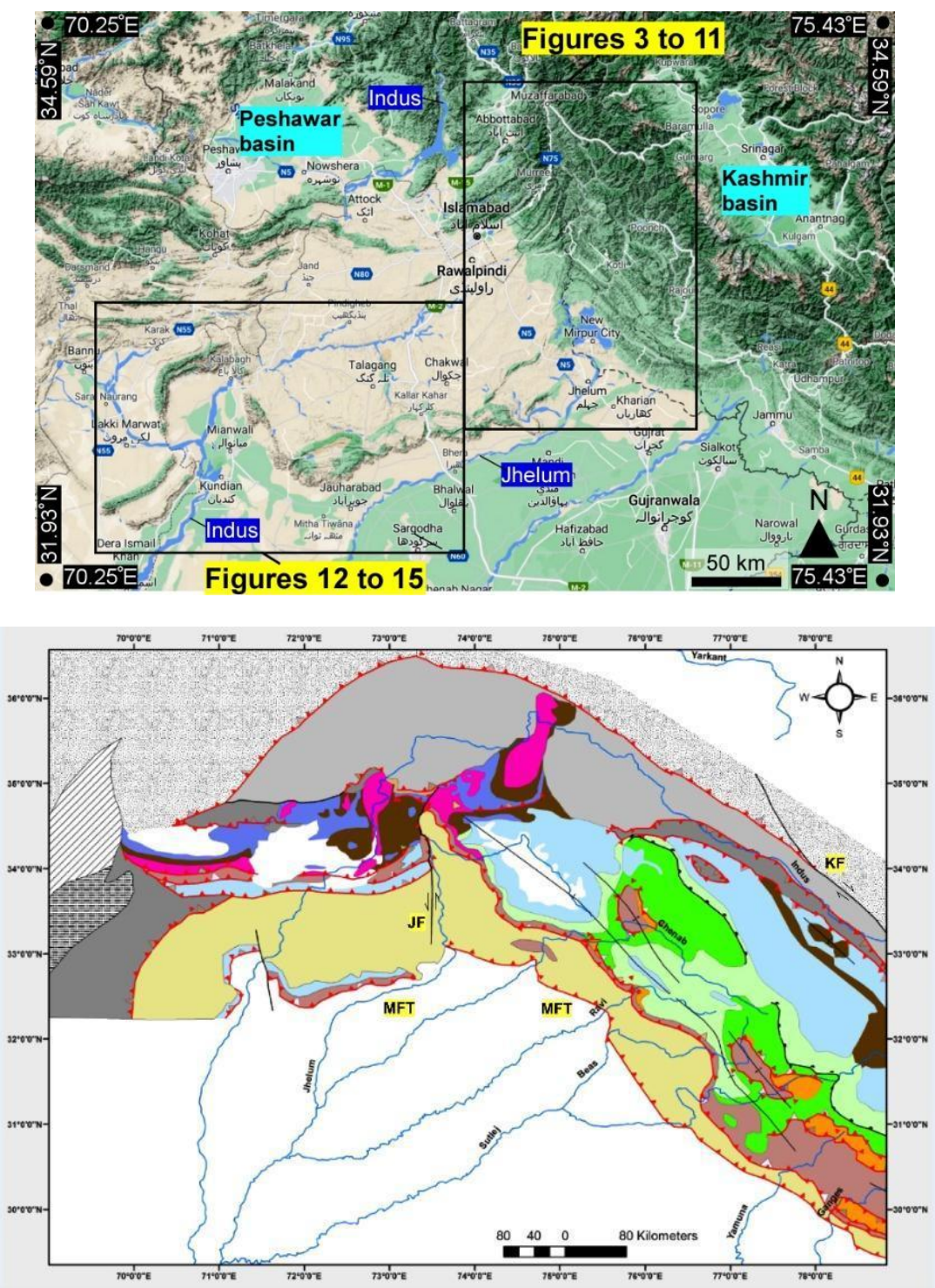

* JF: Jhelum Fault, MFT: Main Frontal Thrust, KF: Karakorum Fault

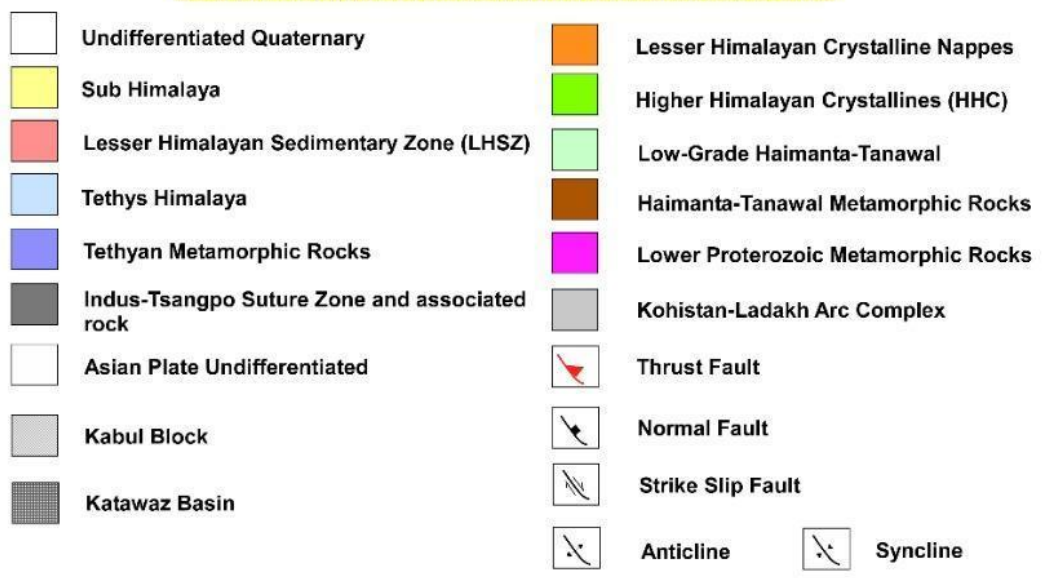

\section{Faure 1}




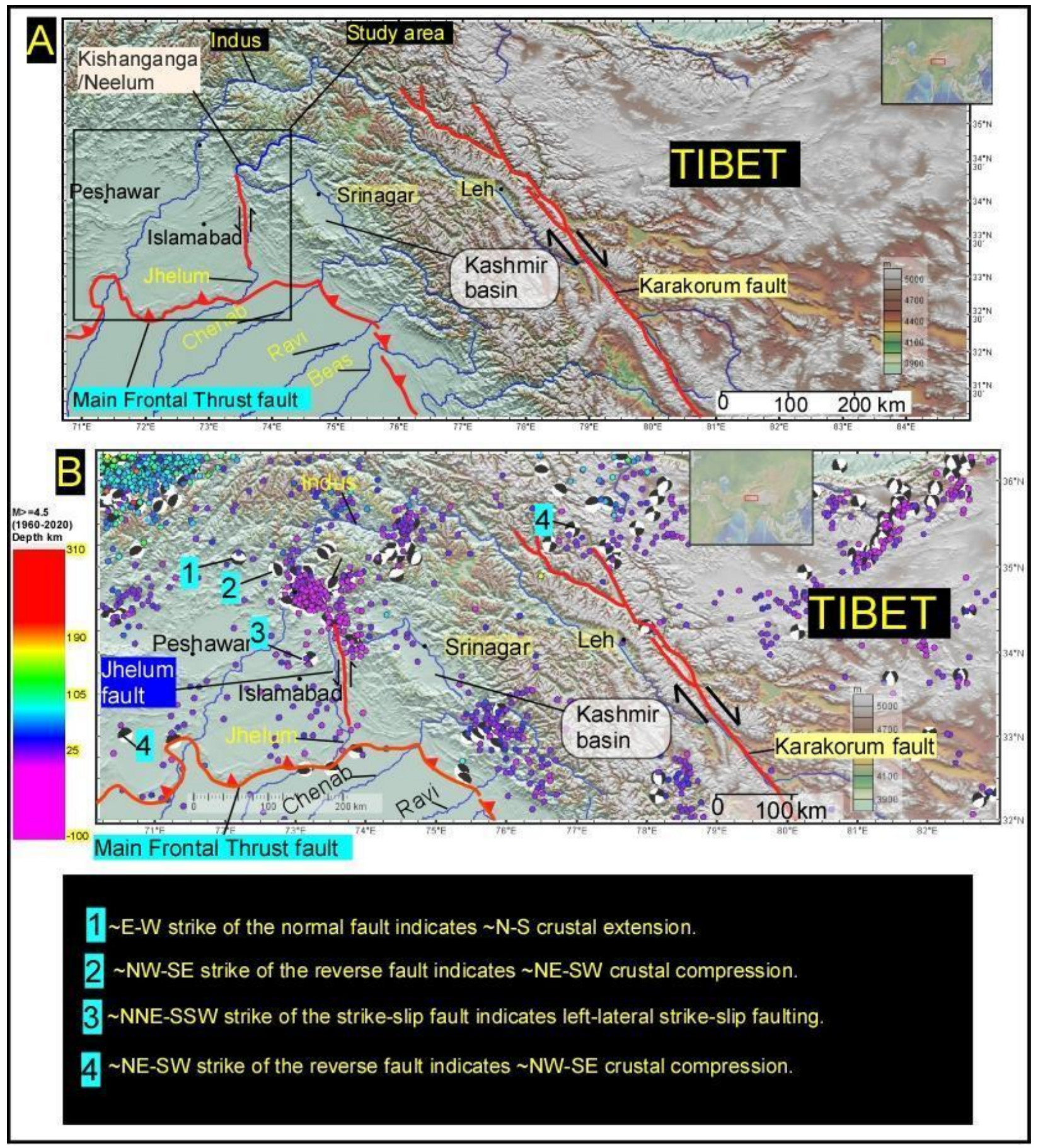

FIGURE 2 


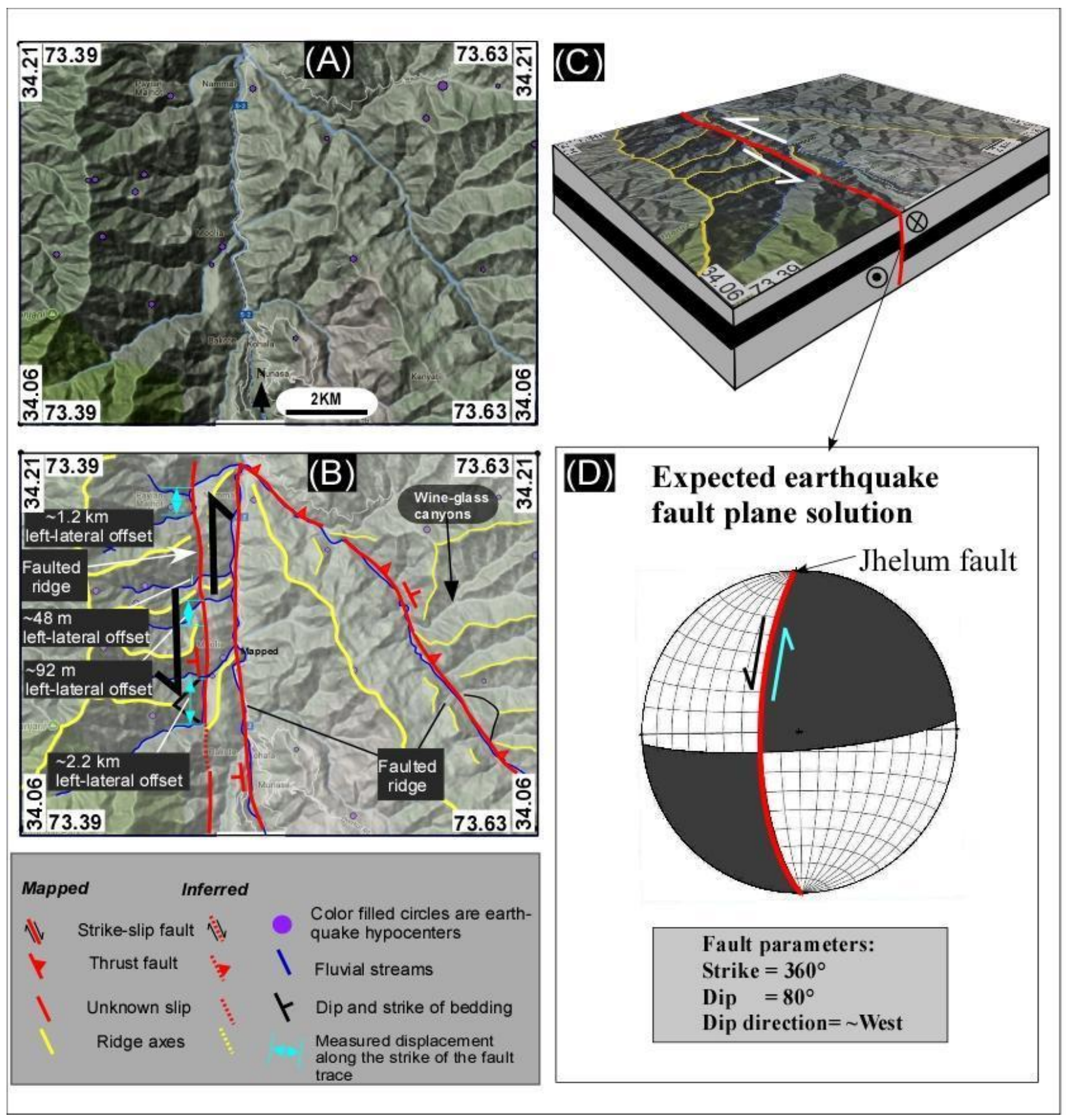

FIGURE 3 


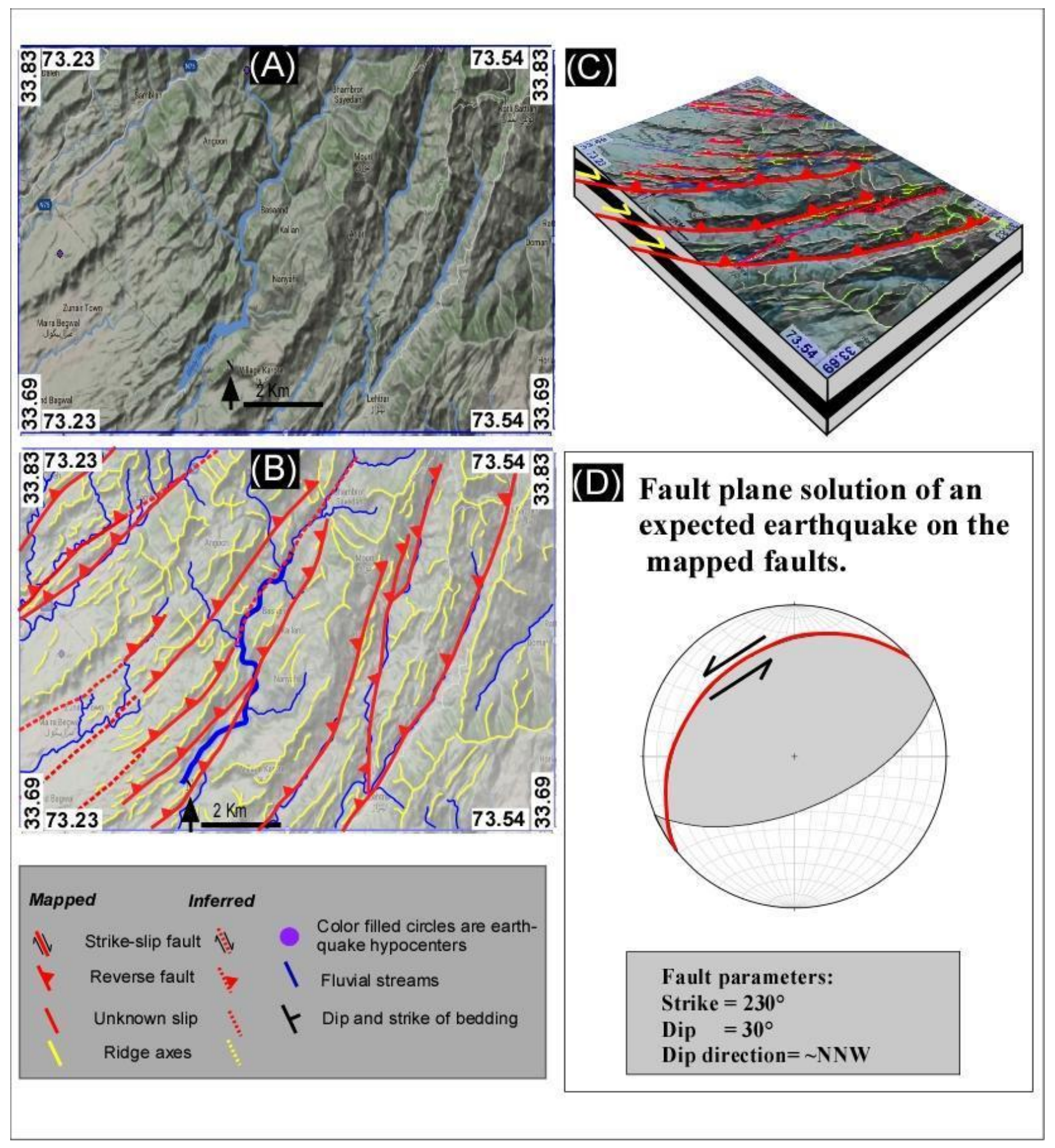

FIGURE 4 


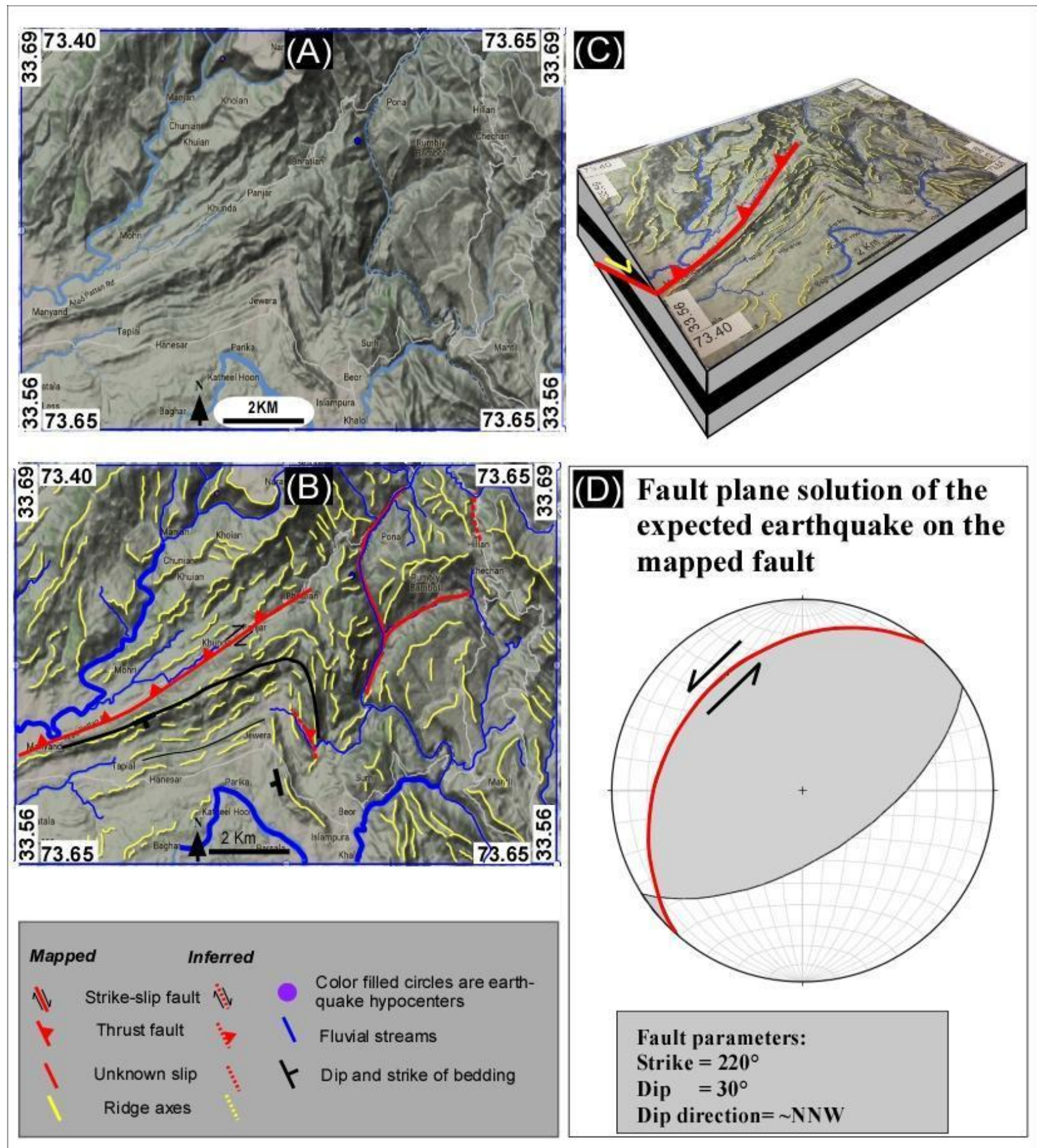

FIGURE 5 

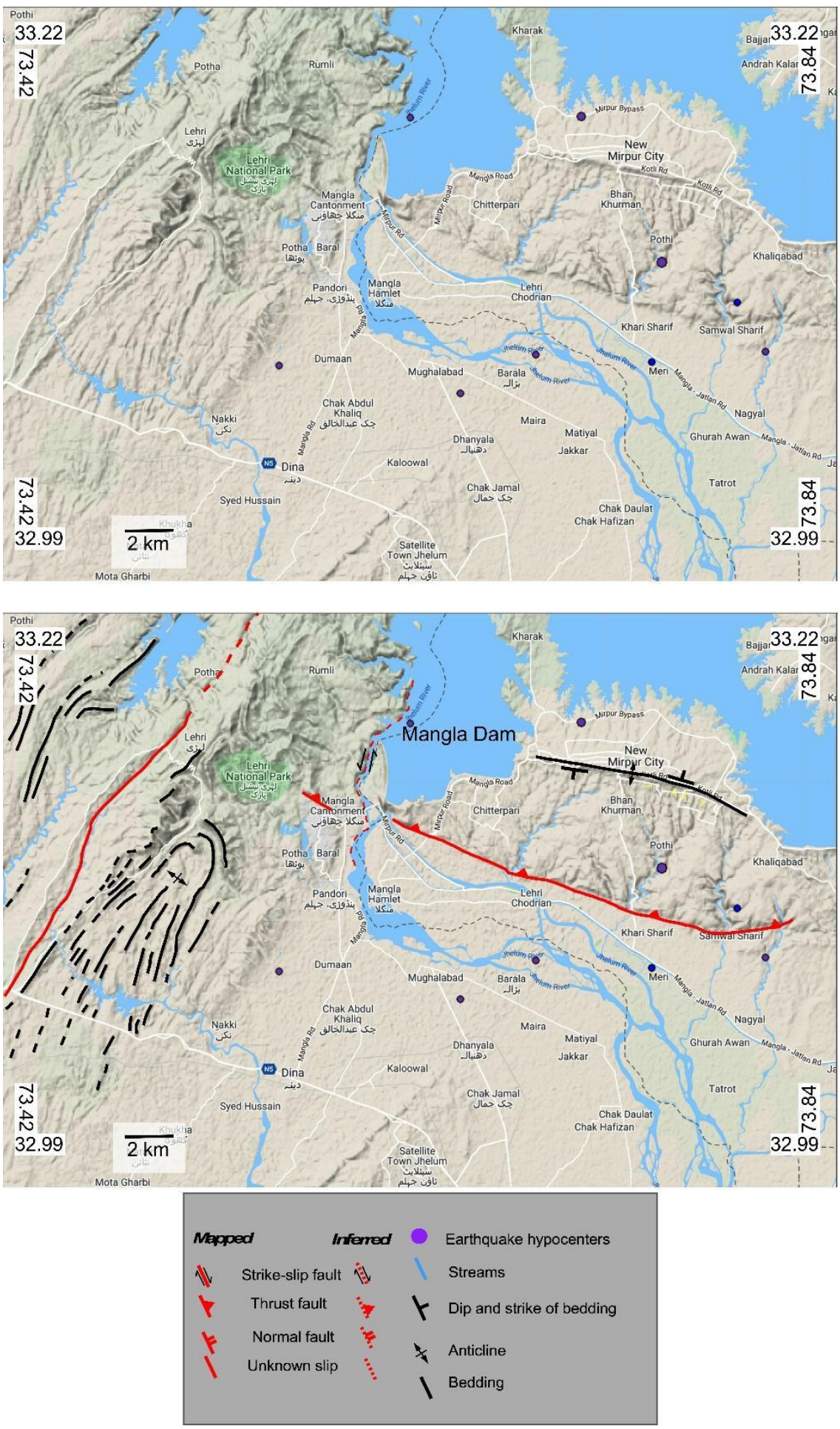

FIGURE 6 

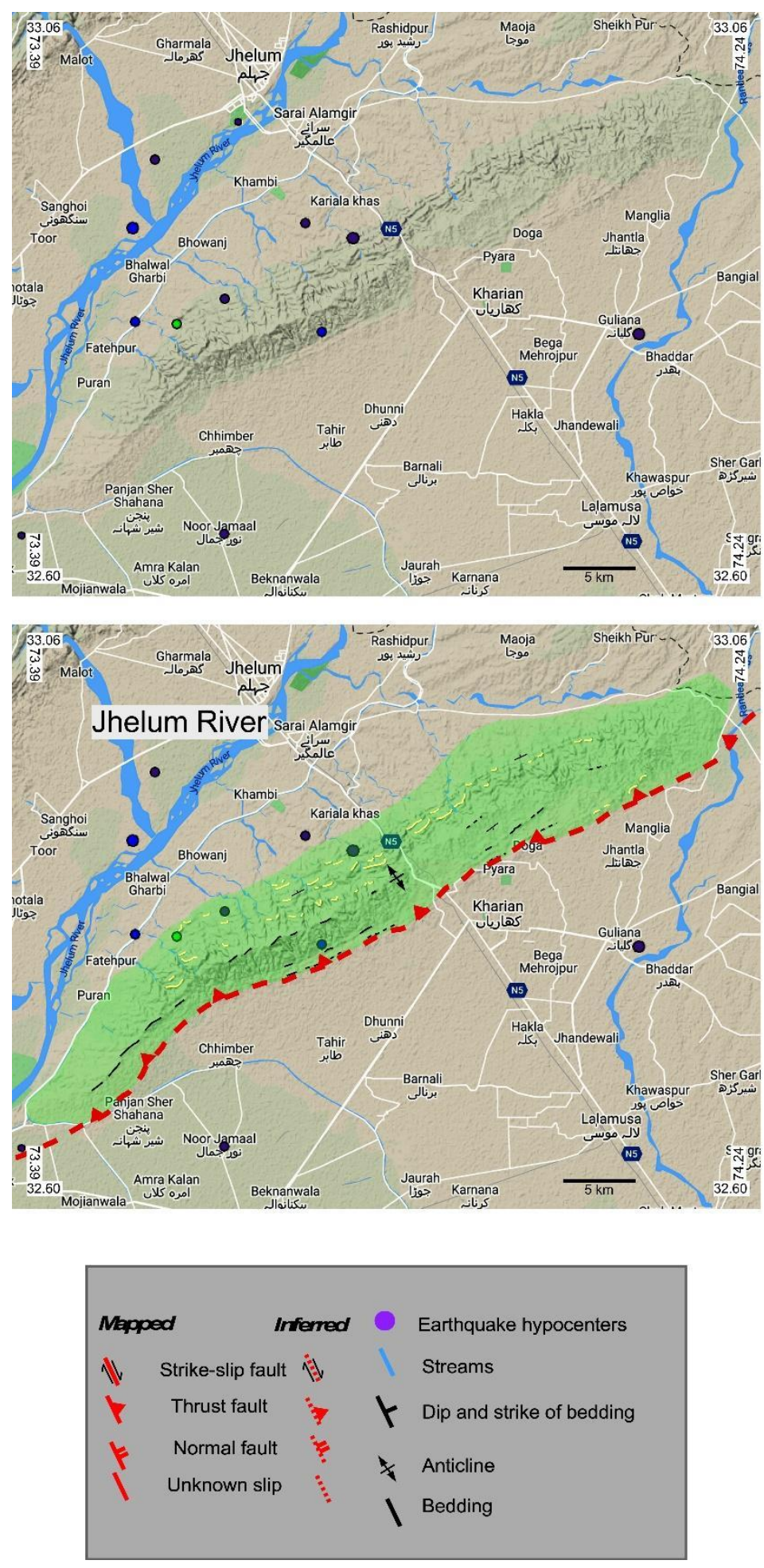

FIGURE 7 


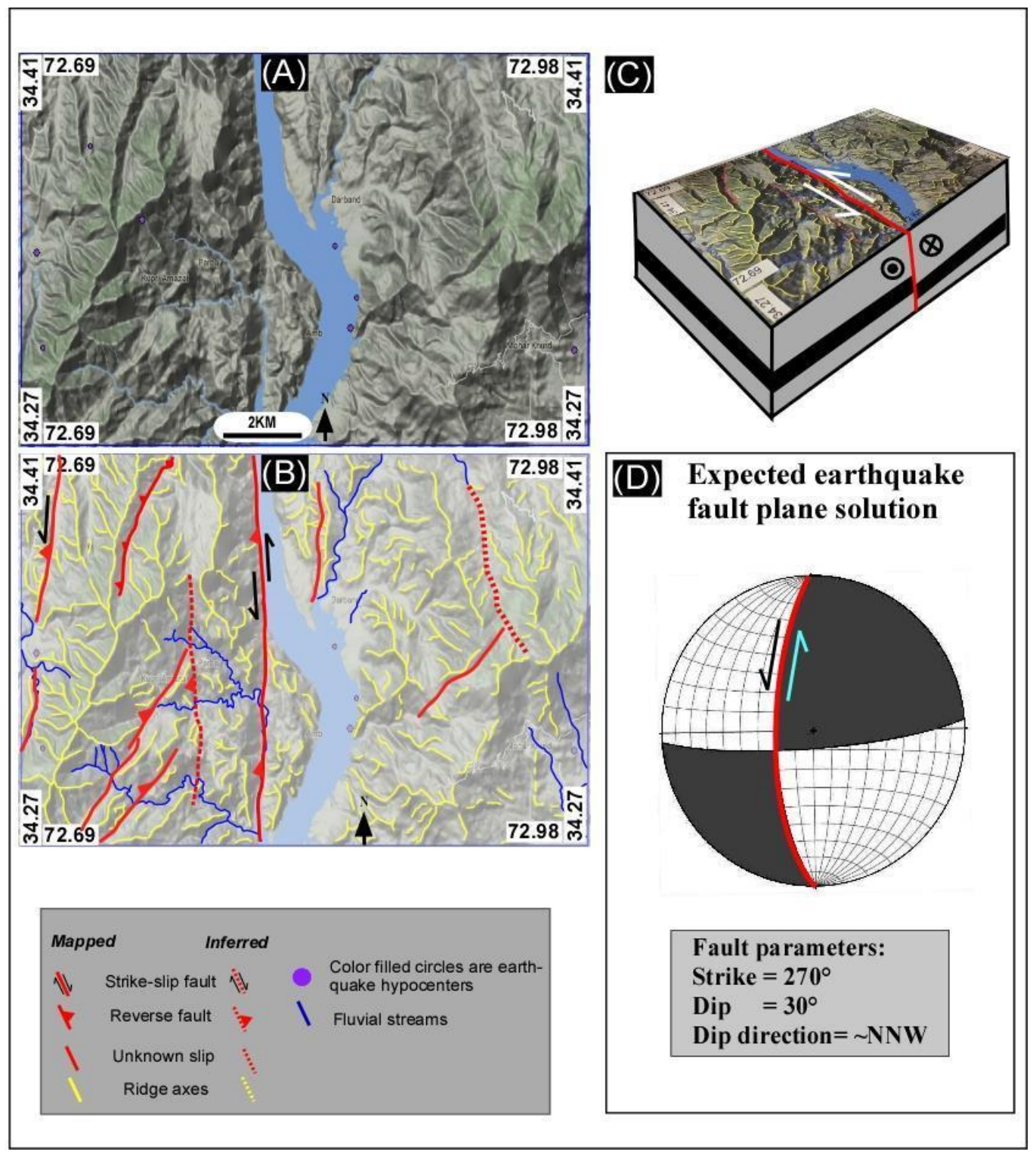

\section{FIGURE 8}




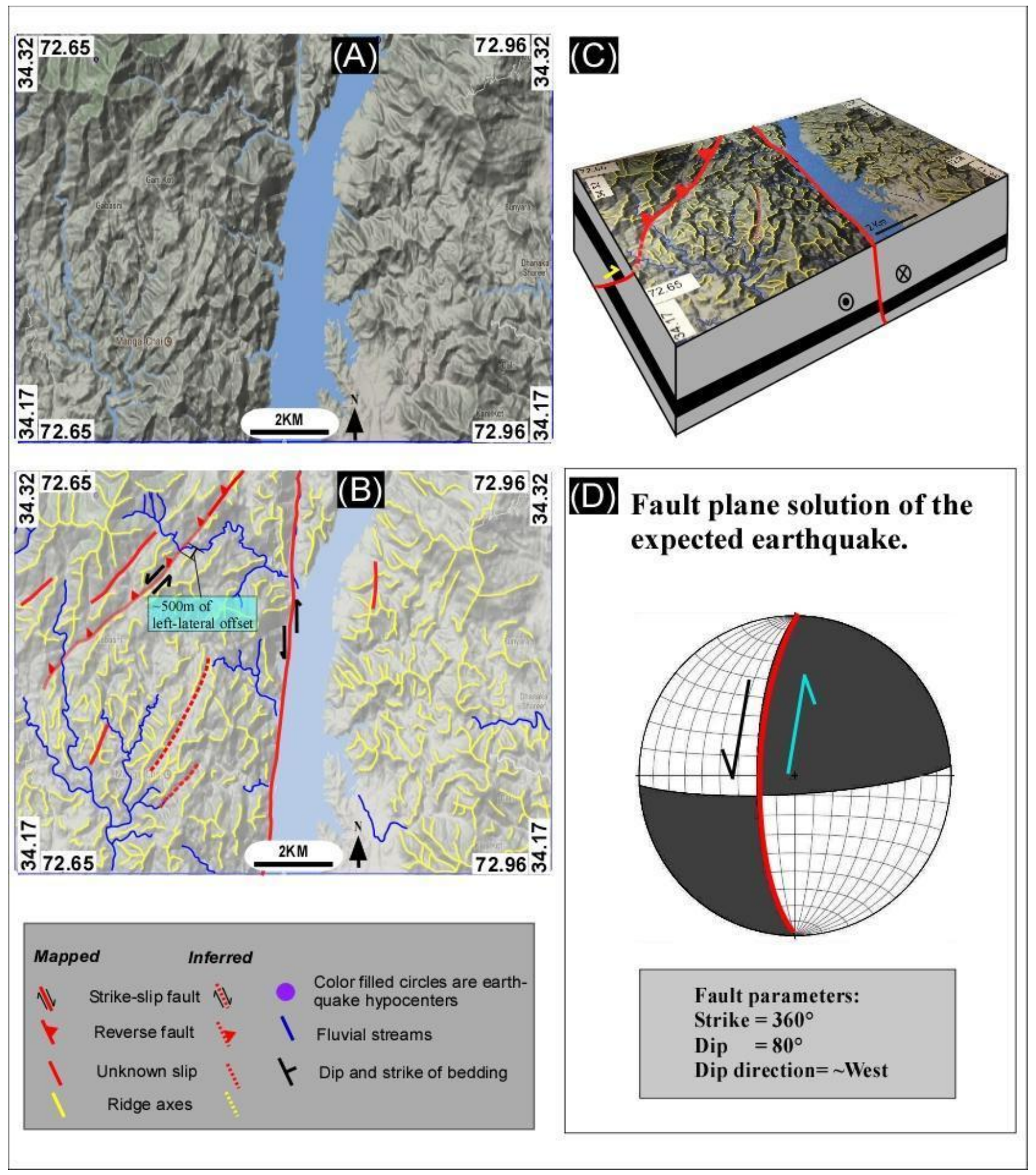

FIGURE 9 


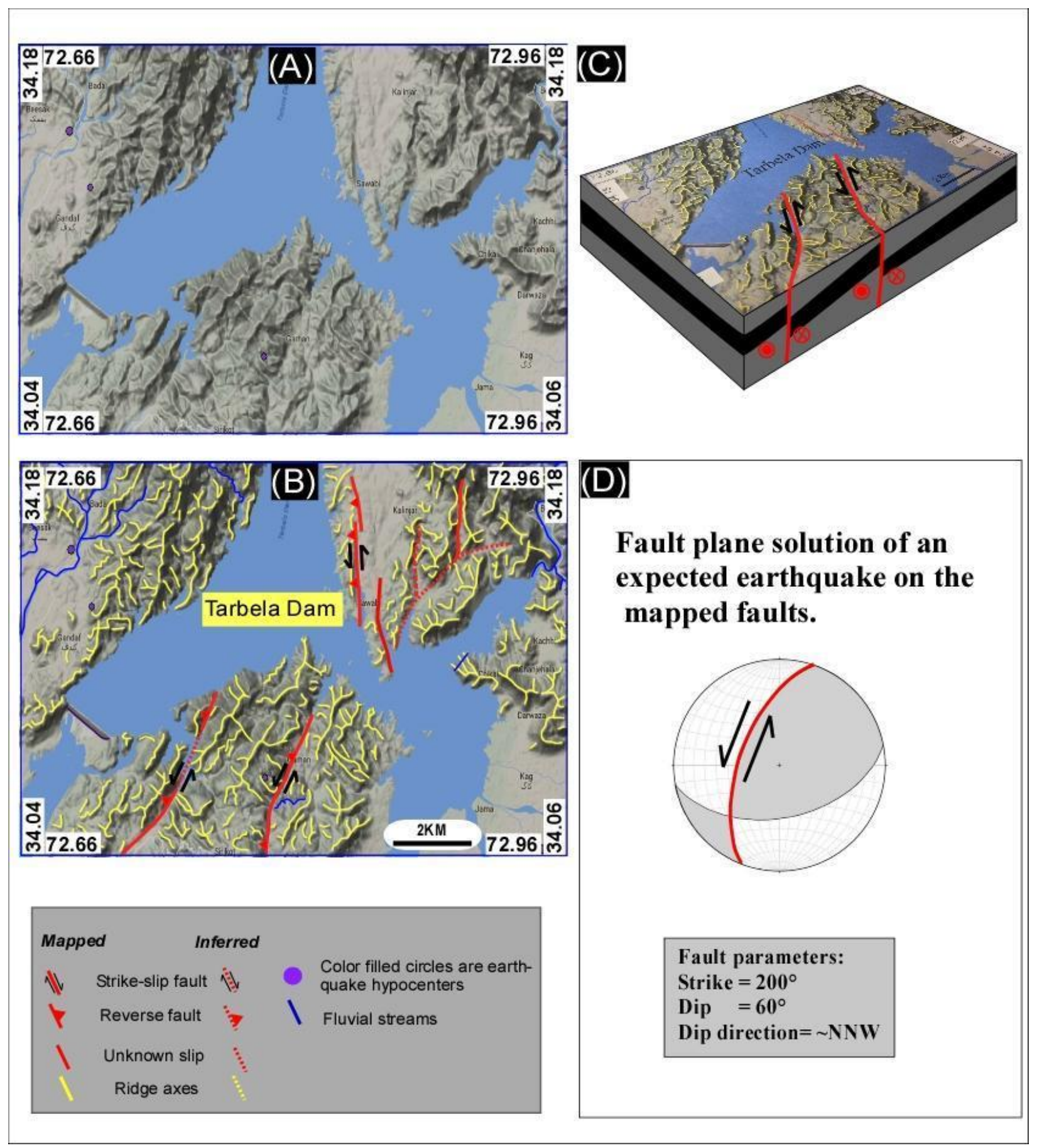

FIGURE 10 


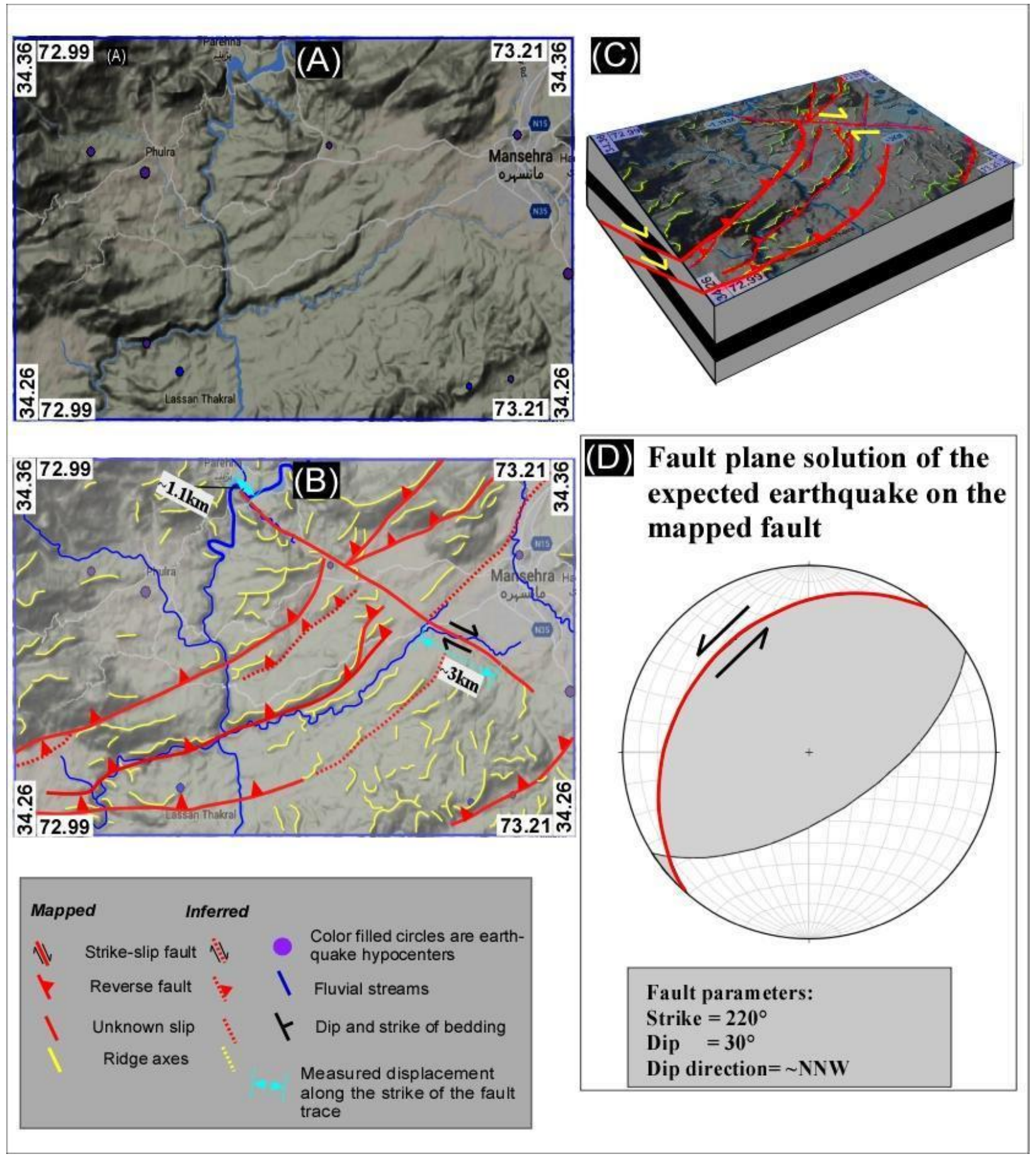

\section{FIGURE 11}




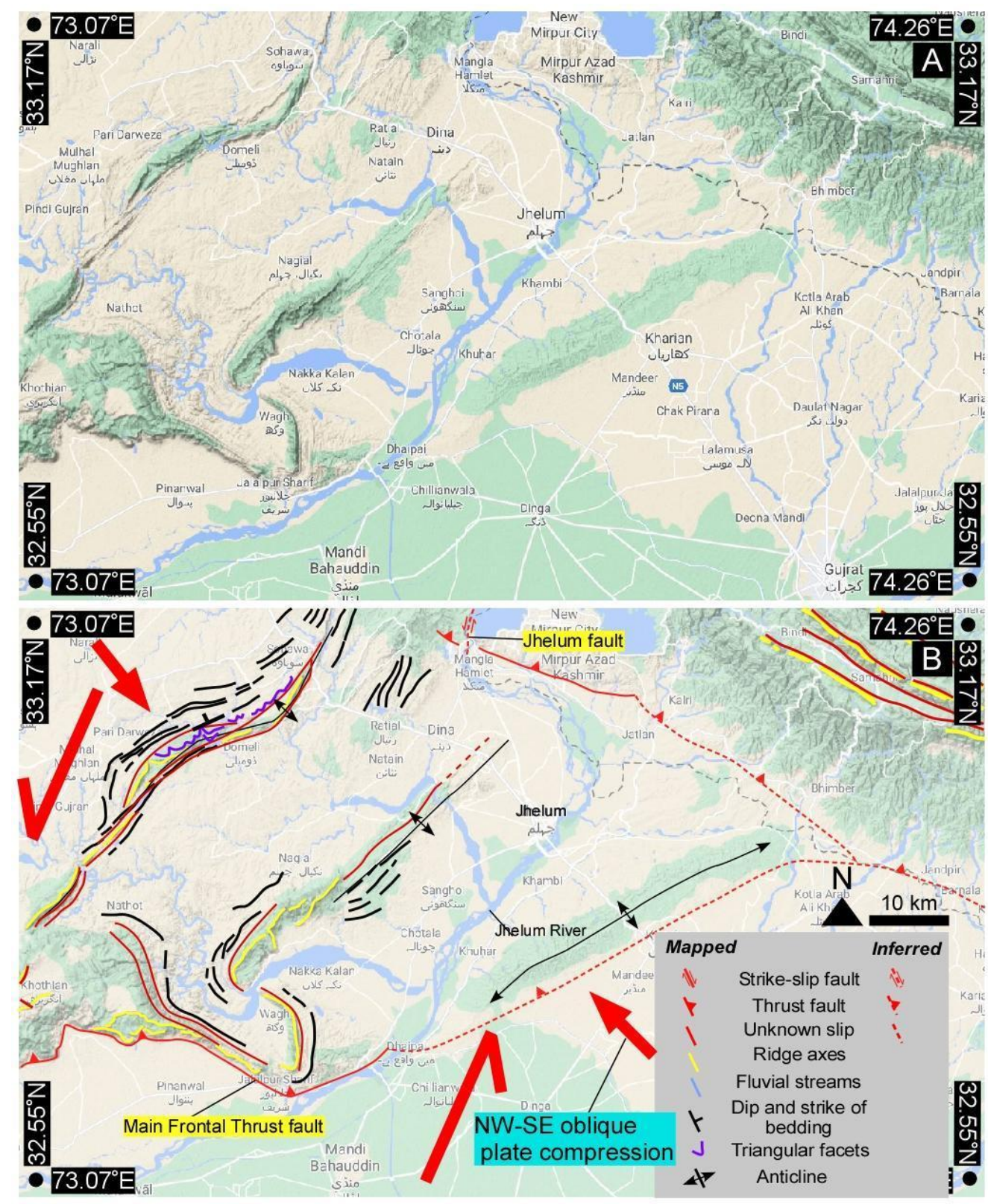

FIGURE 12 


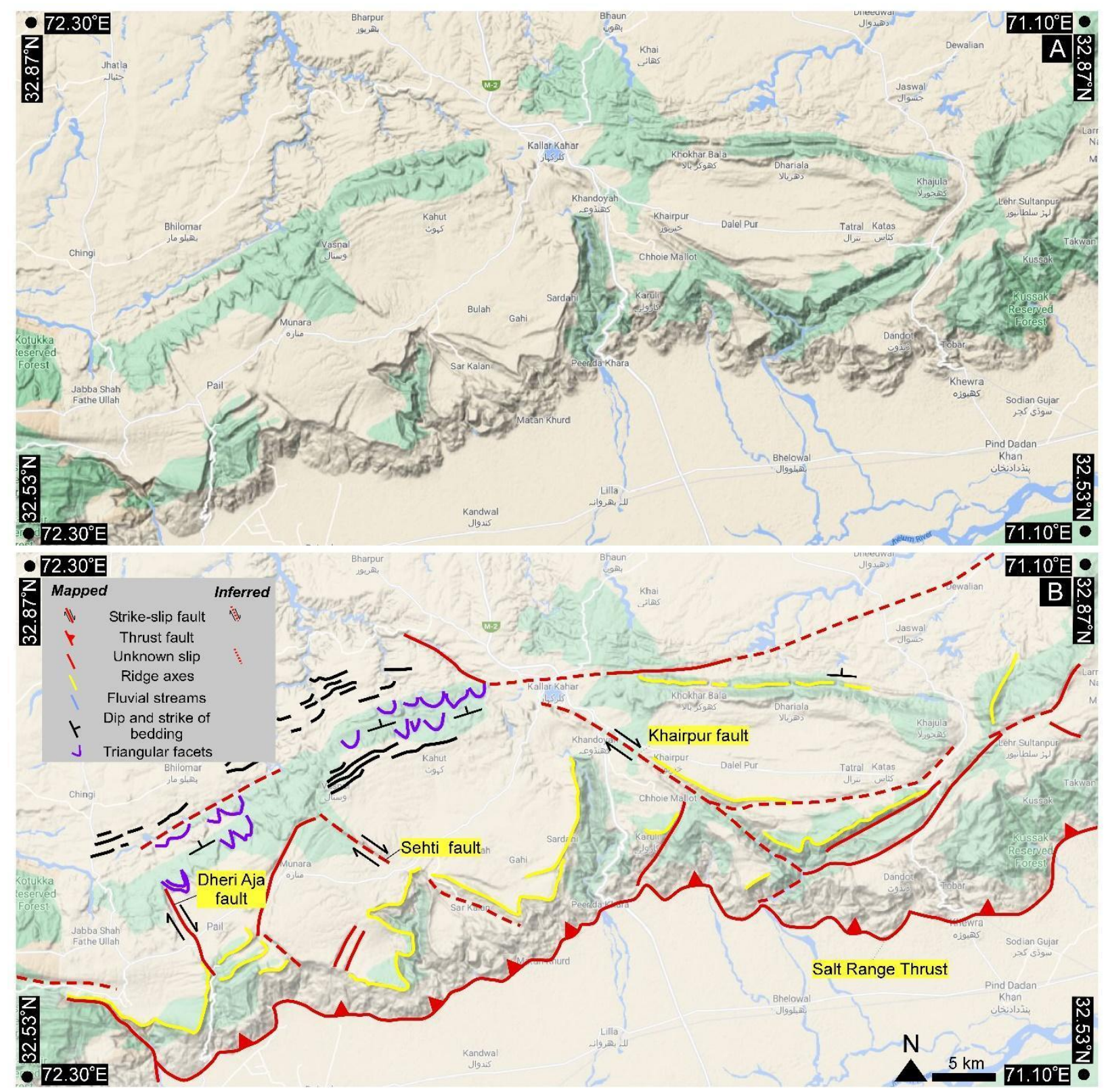

FIGURE 13 


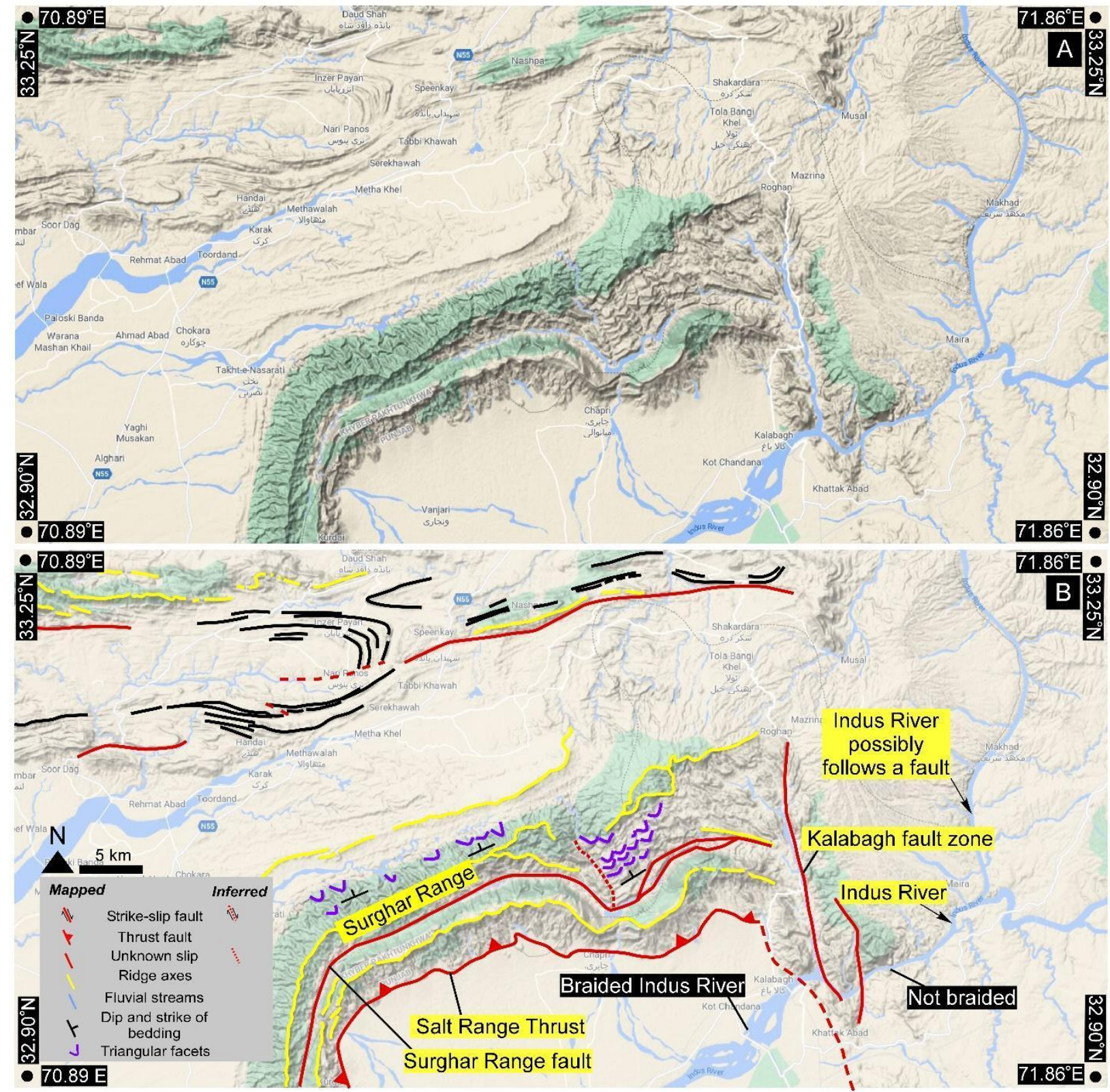

FIGURE 14 


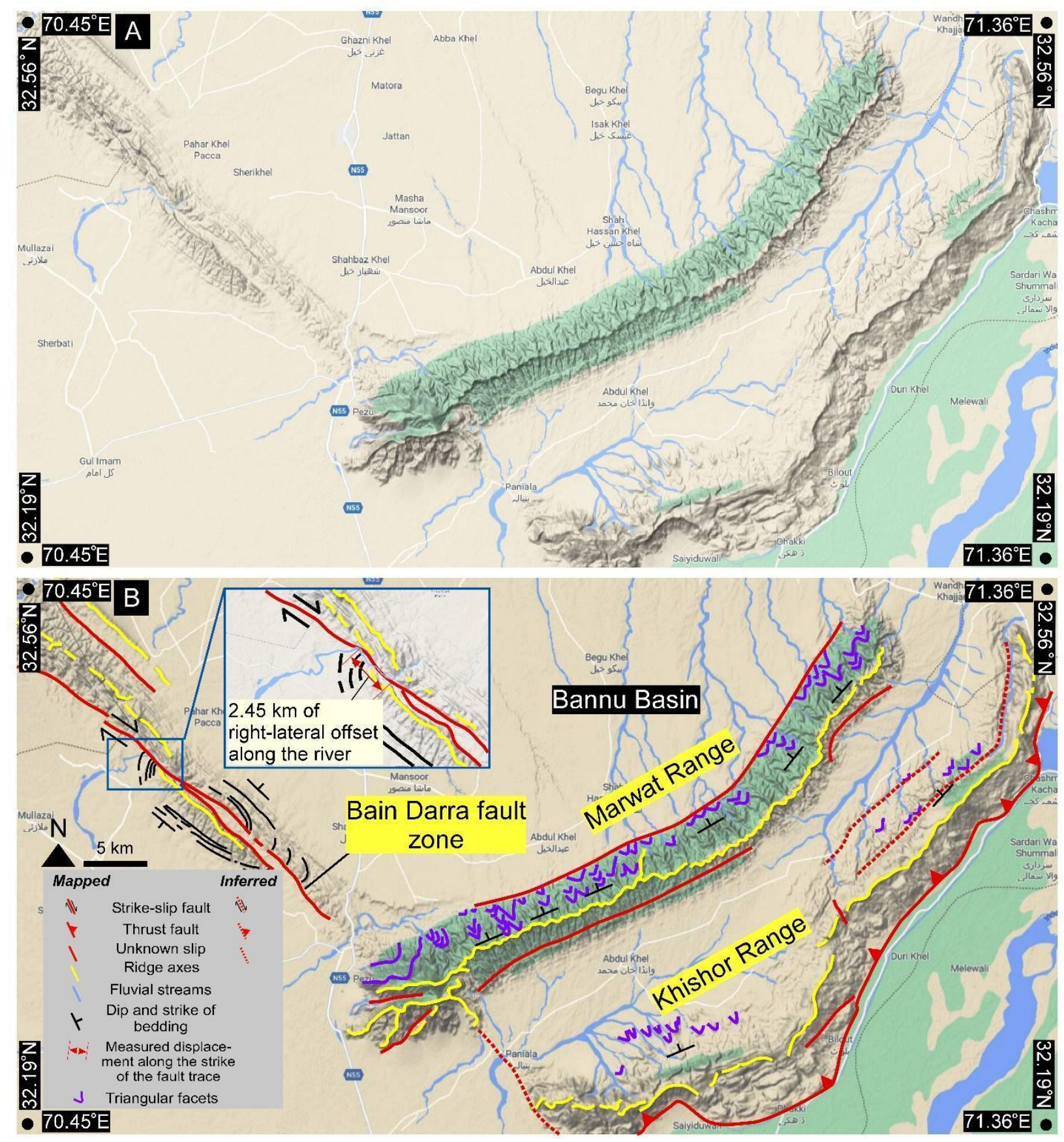

FIGURE 15 


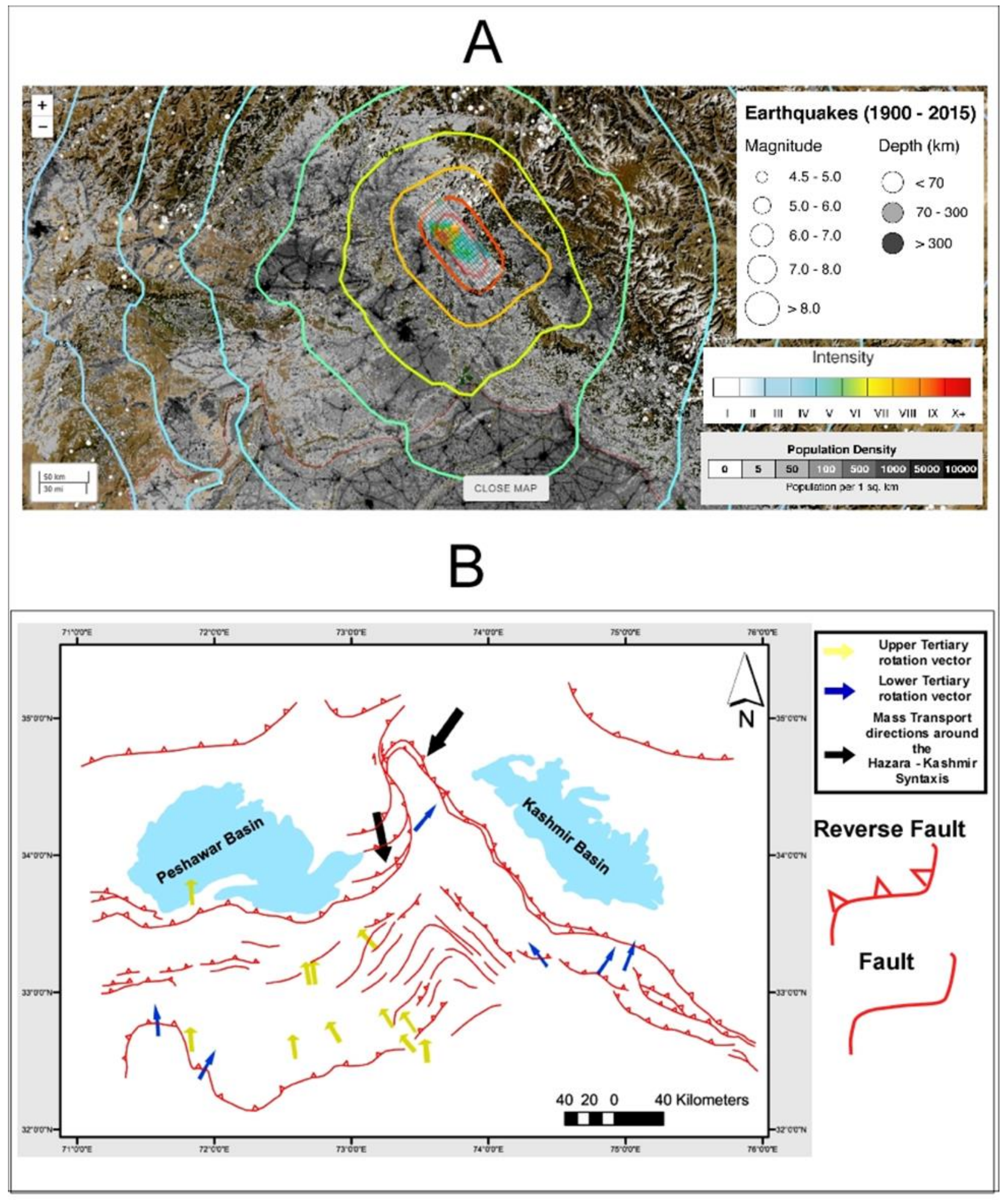

FIGURE 16 

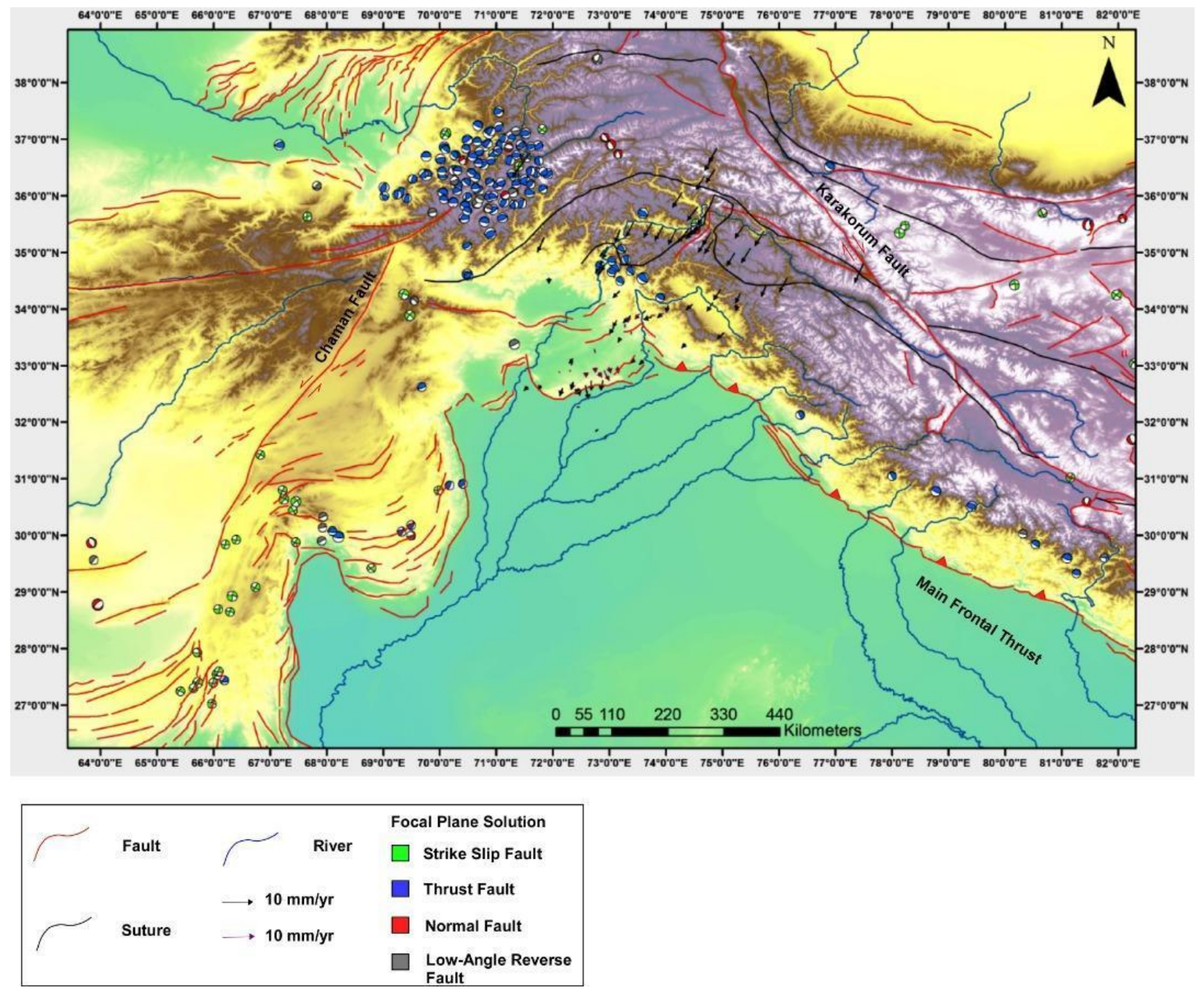

FIGURE 17 


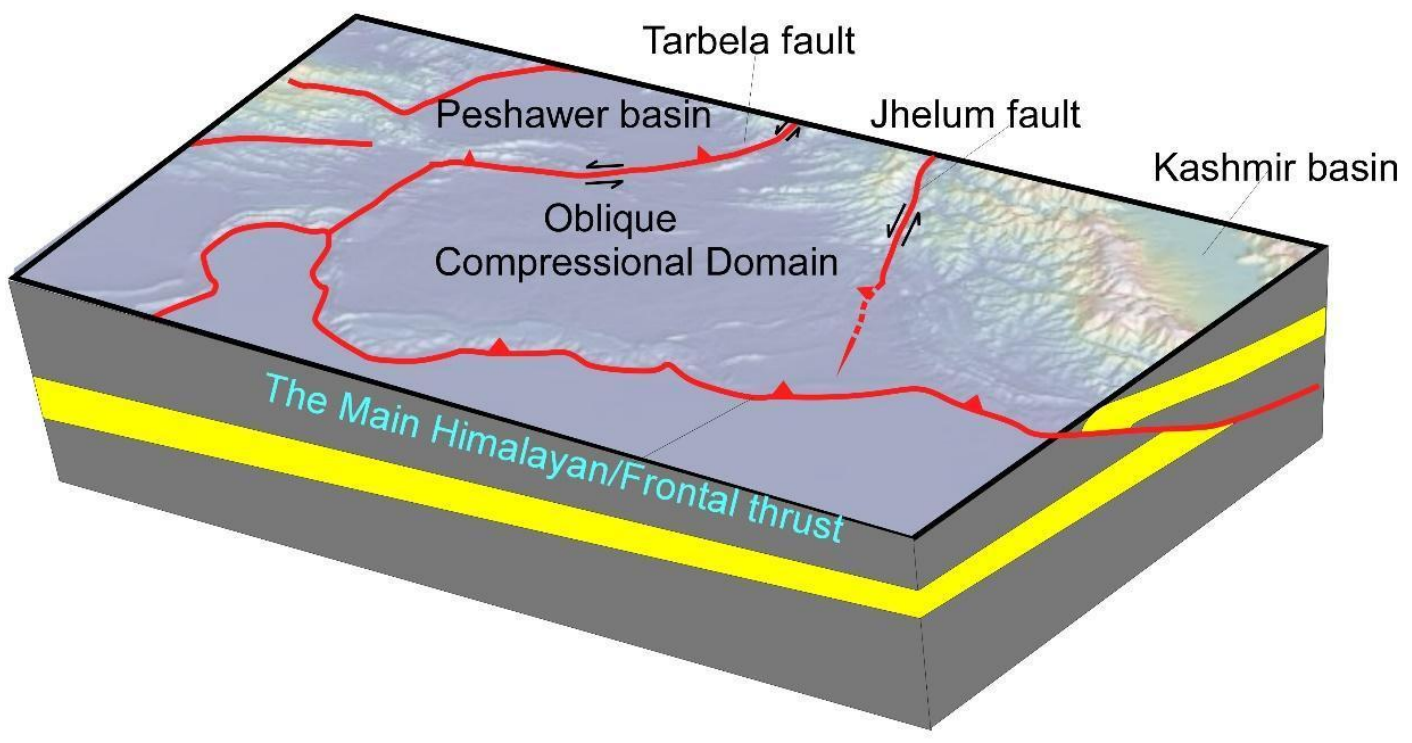

FIGURE 18 